\title{
BULLETIN
}

\author{
OF THE
}

\section{UNITED STATES}

\section{GEOLOGICAL SURVEY}

No. 9

$\triangle$ REPORT OF WORK DONE IN THE WASHINGTON LABORATORY

DURING THE FISCAL YEAR 1883-84

WA S H INGT ON

GOVERNMENT PRINTING OFFIOE 



\section{A D V R R T H M E N T.}

(Bullatin No. 9.)

The publications of the United States Geological Survey are issued in accordance with the statate, approved March 3,1879, which declares that-

"The publications of the Geological Survey shall consist of the annual report of operations, geological and economic maps illustrating the resources and classifications of the lands, and reports upon general and economic geology and paleontology. The annual report of operations of the Geological Survey shall accompany the annual report of the Secretary of the Interior. All special memoirs and reports of said Survey shall be issued in uniform quarto series if deemed necessary by the Director, but otherwise in ordinary octavos. Three thousand copies of each shall be published for scientifio exchanges and for sale at the price of publication; and all literary and cartographic materials received in exchango shall be the property of the United States and form a part of the library of the organization. And the money resulting from the sale of such publications shall be corered into the Treasury of the United States."

On July 7,1882 , the following joint resolution, referring to all Government publications, was passed by Congress :

"That, whenever any document or report shall be ordered printed by Congress, there shall be printed, in addition to the number in each case stated, the ' usual number' $[1,900]$ of copies for binding and distribution among those entitled to receive them."

Under these general laws it will be seen that none of the Survey publications are furnished to it for gratuitous distribution. The 3,000 copies of the Annual Report are distributed through the document rooms of Congress. The 1,900 coptes of each of the publications are distributed to the officers of the legislative and executive Departments and to stated depositories throughout the United States.

Except, therefore, in those cases where an extra number of any publication is supplied to this office: by special resolution of Congress, as has been done in the case of the Second, Third, Fourth, and Fiftle Annual Reports, or wherea number has been ordered for its use by the Secretary of the Interior, as in the case of Williams's Mineral Resources, the Survey has no copies of any of its publications for gratuitous distribution.

\section{ANNUAL REPORTS.}

Of the Annual Reports there have been already published:

I. First Annual Report to the Hon. Carl Schurz, by Clarence King. 1880. $8^{\circ}$. 79 pp. 1 map.-A .preliminary report describing plan of organization and publications:

II. Report of the Director of the United States Geological Survey for 1880-'81, by J. W. Powell. 1882. $8^{\circ} . \quad l v, 588$ pp. 61 pl., 1 map.

III. Third Annual Report of the United States Geological Survey, 1881-'82, by J. W. Powell. 1883. $8^{\circ}$. xviii, $564 \mathrm{pp}$. . $67 \mathrm{pl}$. and maps.

IV. Fourth Annual Report of the United States Geological Survey, 1882-'83, by J. W. Powelt. 1884. 80. xii, 473 pp. 85 pl. and maps.

The Fifth Annual Report is in press.

\section{MONOGRAPHS.}

So far as alreacty determined apon, the list of the Monographs is as follows:

I. The Precious Metals, by Clarence King. In preparation.

II. Tertiary History of the Grand Cañon District, with atlas, by Capt. C. E. Dutton. Published:

III. Geology of the Comstock Lode and Washoe District, with atlas, by George F. Becker. Pubo lished.

IV. Comstock Mining and Miners, by Eliot Lord. Published.

V. Copper-bearing Rocks of Lake Superior, by Prof. R. D. Irving. Published.

VI. Older Mesozoic Flera of Virginia, by Prof. William M. Fontaine. Published.

VII. Silver-lead Deposits of Eureka, Nevada, by Joseph S. Curtis. Published.

VIII. Paleontology of the Eureka District, Nevada, by Charles D. Walcott. In press.

IX. Brachiopoda and Lamellibranchiata of the Green Marls and Clays of New Jerser, by R. P. Whitfield. 


\section{ADVERTISEMENT.}

Geology and Mining Industry of Leadville, witl atlas, by S. F. Emmons. In preparation. Geology of the Eureka Mining District, Nevada, with atlas, by Arnold Hague. In preparation. Iake Bonneville, by G. K. Gilbert. In preparation.

Dinocerata. A monograph on an extinct order of Ungulates, by Prof. O. C. Marsh. In preparation. :Sauropoda, by Prof. O. C. Marsh. In preparation.

:Stegosauria, by Prof. 0. C. Marsh. In preparation.

Of these Monographs, Nos. II, II, IV, V, VI, and VII are now published, viz:

II. Tertiary History of the Grand Cañon District, with atlas, by C. E. Dutton, Capt. U. S. A. 1882. 40 . $264 \mathrm{pp} .42 \mathrm{pl}$. and atlas of 26 double sheets folio. Price $\$ 10.12$.

III. Geology of the Comstock Lode and Washoe District, with atlas, by G. F. Becker. 1882. $4^{\circ} . \quad x \nabla$, $422 \mathrm{pp} .7 \mathrm{pl}$. and atlas of 21 sheets folio. Price $\$ 11$.

IV. Comstock Mining and Miners, by Eliot Lord. 1883. $4^{\circ}$. xvi, 451 pp. 3 pl. Price $\$ 1.50$.

V. Copper-bearing Rocks of Lake Superior, by Prof. R. D. Irving. 1883. $4^{\circ}$. xiv, 464 pp. 29 pl. Price\$-.

VI. Contributions to the Knowledge of the Older Mesozoic Flora of Virginia, by William M. Fontaine. 1883. 4०. xi, 144 pp. 54 l. 54 pl. Price \$-.

VII. Silver-lead Deposits of Enreka, Nevada, by Joseph S. Curtis. $1884.4^{\circ}$. xiii, 200 pp. 15 pl. Price \$-

Nos. VIII and IX are in press and will soon appear. The others, to which numbers are not assigned, are in preparation.

\section{BULLETINS.}

The Bulletins of the Survey will contain such papers relating to the general purpose of its work as do not properly come under the heads of Annual Reports or Monographs.

Each of these Bthllins will contain but one paper, and be complete in itself. They will, however, Te numbered in a continuous series, and will in time be united into volnmes of convenient size. To facilitate this, each Bulletin will have two paginations, one proper to itself and one which belongs to it as part of the volume.

Of this series of Bulletins, Nos. 1, 2, 3, 4, 5, 6, 7, 8, and 9 are already published, viz:

7. On Hypersthene-Andesite and on Triclinic Pyroxene in Augitic Rocks, by Whitman Cross, with a Geological Sketch of Buffalo Peaks, Colorado, by S. F. Emmons. 1883. $8^{\circ}$. 42 pp. 2 pl. Price 10 cents.

2. Gold and Silver Conversion Tables, giving the coining value of Troy ounces of fine metal, \&c., by Albert Williams, jr. 1883 . $8^{\circ}$. ii, 8 pp. Price 5 cents.

3. On the Fossil Faunas of the Upper Devonian along the meridian of $76^{\circ} 30^{\prime}$, from Tompkins County, New York, to Bradford County, Penusylvania, by Henry S. Williams. 1884. $8^{\circ} .36$ pp. Price 5 cents.

4. On Mesozoic Fossils, by Charles A. White. 1884. $80.36 \mathrm{pp} .9 \mathrm{pl}$. Price 5 cents.

5. A Dictionary of Altitudes in the United States, compiled by Henry Gannett. 1884. $8^{\circ} .325 \mathrm{pp.}$ IPrice 20 cents.

6. Elevations in the Dominion of Canada, by J. W. Spencer. $1884.8^{\circ} .43 \mathrm{pp}$. Price 5 cents.

7. Mapoteca Geologica Americana. A Catalogue of Geological Maps of America (North and South), 2752-1881, by Jules Marcou and John Belknap Marcon. 1884. 8०. 84 pp. Price 10 cents.

8. On Secondary Enlargement of Mineral Fragments in Certain Rocks, by R. D. Irving and C. R. \$anhise. 1884. $8^{\circ}$. 56 pp. Price 10 cents.

9. A Report of Work done in the Washington Laboratory daring the fliscal year 1883-'84. F. W. Clarke, chief chemist; T. M Chatard, assistant. 1884. $8^{\circ} .40$ pp. Price 5 cents.

\section{Statistical Papers.}

A fourth series of publications having special reference to the mineral resources of the United istates is contemplated; of that series the first has been published, viz: Mineral Resources of the Evited States, by Albert Williams, jr. 1883. $8^{\circ}$. xvii, 813 pp. Price 50 cents.

'Correspondence relating to the publications of the Survey, and all remittances, which must be by ppostal note or money order, should be addressed to the

Director of the United Stateg Geological Survey, Washington, D. $O$.

W ABhington, D. C., August 30, 1884. 


\title{
DEPARTMENT OF THE INTERIOR
}

\section{B ULLETIN}

\author{
OF THE
}

UNITED STATES

\section{GEOLOGICAL SURVEY}

No. 9

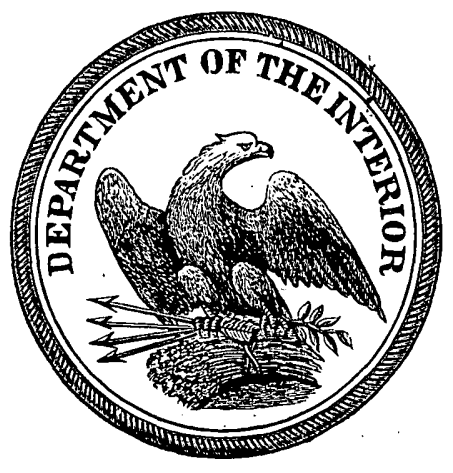

WASHINGTON

GOVHRAMET PRINTING OFFIOE 1884 


\section{UNITED STATES GEOLOGICAL SURVEY}

J. W. POWELL DIRECTOR

\section{A REP0RT OF WORK DONE}

IN THE

\section{WASHINGTON LABORATORY}

DURING THE

FISCAL YEAR 1883-'84

F. W. Clarke Chief Chemist

T. M. CHATARD Assis'tan'T Chemist

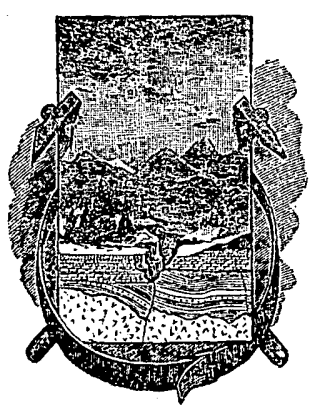

WASHINGTON

GOVERNMENI PRINTLNG OFFIOE 


\section{CONTENTS.}

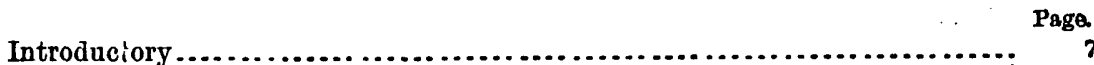

Mineral, rock, and ore analyses..................................... 9

Gahnite, from Montgomery County, Maryland ................. 9

Jade and pectolite, from Alaska ............................... 9

- Saussurite, from Shasta County, California ...................... 10

Allanite, from Topsham, Maine.............................. 10

Beryl, from Greene County, Tennessee ......................... 11

Damourite, from Stoneham, Maine ............................ 11

Margarite................................................. 11

Cimolite, from Norway, Maine............................... 12

Halloysite, from California.................................. 12

Prochlorite .............................................. 13

Alum rock, from Grant County, New Mexico..................... 13

Scoriaceous Obsidian, from Mono Valley, California................ 14

Powder, from Truckee River, Nevada............................ 14

Marl, from Pyramid Lake, Nevada ........................... 14

Clays, from Mill City, Nevada................................. 15

Basalt from Mount Thielson, Oregon ......................... 15

Basalt, from Pit River, California ........................... 16

Dacites, from Lassen's Peak, California.......................... 16

Limestones, from Moundsville, West Virginia.................... 17

Magnetite, from near Bozeman, Montana ..................... 17

Limonite, from Canaan Mountain, West Virginia.................. 18

Coal, from Cranston, Rhode Island.............................. 18

Water analyses ................................................. 19

Pyramid Lake, Nevada...................................... 19

Winnemucca Lake, Nevada................................ 21

Walker Lake, Nevada........................................ . 22

Walker River, Nevada..................................... 23

Humboldt River, Nevada................................... 23

Hot Spring, foot of Granite Mountain, Nevada.................. 24

Hot Spring, Hot Spring Station, Nevada...................... 24

Larger Soda Lake, Ragtown, Nevada ......................... $\quad 25$

Mono Lake, California ....................................... $\quad 26$

Spring on Tufa Crag in Mono Lake, California.................... 27

Warm Spring, Mono Basin, Califoruia ......................... 27

Boiling Spring, Honey Lake Valles, California................... 28

Lake Tahoe, California...................................... 28

Abert Lake, Oregon ........................................ $\quad 28$

Utah Lake, Utah ....................................... 29

City Creek, Utah ........................................ 29

Bear River, Utah .......................................... 30

Utah Hot Springs......................................... $\quad 30$

Livingston Warm Springs, Montana ........................ 31

Warm Springs, Emigrant Gulch, Montana .................... 31

Helena Hot Springs, Montana............................... 32

Mill Creek Cold Spring, Montana............................ 32

Virginia Hot Springs, Bath County, Virginia.................... 33

The estimation of alkalies in silicates, by T. M. Chatard ................. 36

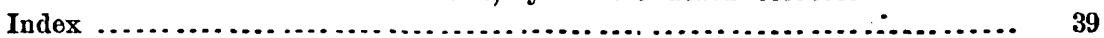





\section{INTRODUCTORY.}

The present bulletin contains the more inportant results obtained in the chemical laboratory of the United States Geological Survey at Washington, between December 12,1883, and June 30,1884. The work here reported was almost.wholly done by Dr. T. M. Chatard and myself, and represents the first fiscal year of our laboratory organization. Other work, carried forward in this laboratory by Dr. F. A. Gooch, and relating mainly to the rocks and waters of the Yellowstone National Park, is reserved for a future bulletin.

In adrlition to the analyses here publisherl, a considerable number of assays, mineral determinations, and qualitative examinations have been made. Several researches have also been begun, but are not yet advanced enough to warrant any announcement. Other bulletins will be issued from time to time, as fast as material accumulates.

F. W. CLARKE. 



\section{WORK DONE IN THE WASHINGTON LABORATORY DURING THE FISCAL YEAR 1883--'84.}

\section{MINERAI, ROCK, AND ORE ANALYSES.}

The mineralogical work of the division of chemistry has been done in close co-operation with the mineral department of the National Museum. Some of the material studied has been received through the latter institution; some has been brought in by field parties of the Survey; some represents our own summer collecting. The rocks, clays, etc., analyzed, have been submitted by other divisions of the survey, and will not be specially discussed in this bulletin. The only novelty in the methods of analysis has been in the use of the bismuth oxide process for the estimation of the alkalies in silicates. This process, as modified by Dr. Chatard, is described later.

GAHNITE FROM GILMORE'S MICA MINE, MOUNTGOMERY COUNTY, MARYLAND.

The locality at which this mineral was found is 12 miles north of Washington, near Colesville, Maryland. The mine has yielded a considerable quantity of. merchantable mica, which occurs in the usual granite vein, associated with quartz, albite, garnet, black tourmaline, and beryl. The last-named mineral is abundant in large but ill-formed crystals. But one specimen of the gahnite was obtained; a dark-green massive specimen, filling a cavity in altered feldspar. Specific gravity 4.59. Analysis by T. M. Chatard :

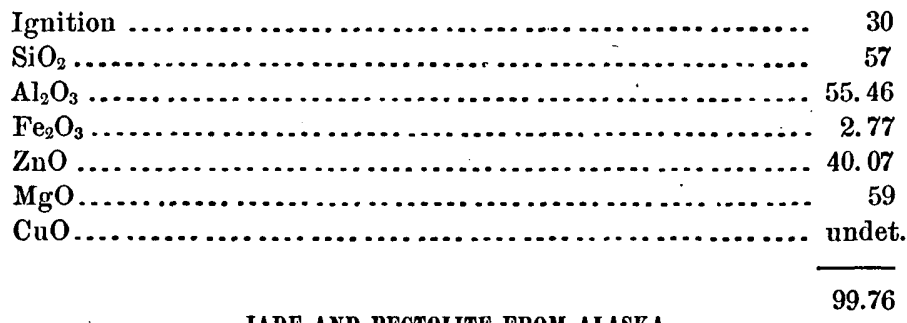

JADE AND PECTOLITE FROM ALASKA.

Among the Eskimo implements collected by the U. S. Signal Service at Point Barrow, Alaska, were a considerable number of a material which appeared to be jade. Of these there were two varieties; one pale apple-green, the other dark-green ; both were highly polished, and exceedingly compact and tough. The specific gravity of the pale-green 
variety was 2.873 , that of the dark material was 3.012. Analyses (Clarke) gave results as follows :

\begin{tabular}{|c|c|c|}
\hline & Pale-green. & Dark-green. \\
\hline $\mathrm{H}_{2} \mathrm{O} \ldots \ldots \ldots$ & 4.09 & 1.41 \\
\hline $\mathrm{SiO}_{2} \ldots \ldots \ldots \ldots$ & 53.94 & 57.01 \\
\hline $\mathrm{FeO} \ldots . . . \ldots \ldots \ldots$ & trace. & 6.95 \\
\hline $\mathrm{CaO} \ldots \ldots \ldots \ldots$ & 32.21 & 12.75 \\
\hline MgO............. & 1.43 & 21.30 \\
\hline $\mathrm{Al}_{2} \mathrm{O}_{3} \ldots \ldots \ldots \ldots$ & 0.58 & 0.42 \\
\hline \multirow[t]{2}{*}{$\mathrm{Na}_{2} \mathrm{O} \ldots \ldots \ldots \ldots$} & 8.57 & \\
\hline & 100.82 & 99.90 \\
\hline
\end{tabular}

The dark-green material is plainly jade, or nephrite, quite analogous in composition to that from the Swiss lake dwellings. The light-green mineral, on the other hand, agrees in composition with pectolite. It is easily fusible, and has, in short, all the essential properties of pectolite. It is, therefore, a new and interesting variety of that well-known species.

The Eskimo of Point Barrow say that the jade and jade-like minerals used by them come from some point to the eastward. The locality itself, we believe, has not yet been visited by civilized men. Whether both minerals are found at the same place or not cannot be stated; but we hope that before long more definite information may be secured.

\section{SAUSSURITE FROM OALIFORNIA.}

Found in a gabbro collected by Mr. J. S. Diller, thirty-seven miles north of Pit River Ferry, Shasta County. The mineral is nearly white, with a greenish-gray cast, and has a specific gravity of 3.148. Associated with green diallage. Analysis by F. W. Clarke:

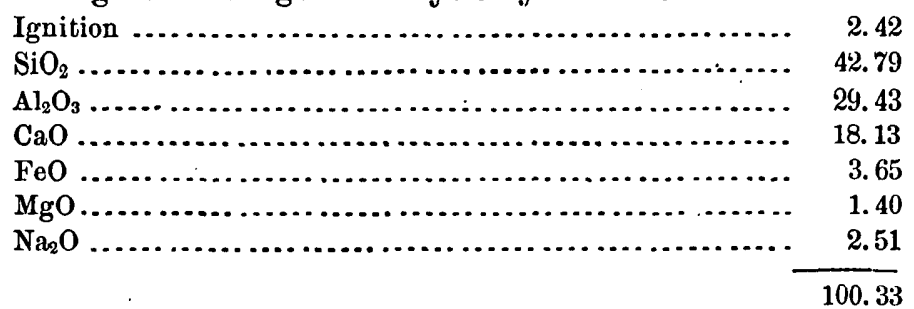

ALLANITE FROM TOPSHAM, MAINE.

Abundant in slender black prisms at Sprague's granite quarrv. The crystals are usually much rusted upon the surface, and are known to the local quarrymen as "nails." Analysis by F. W. Clarke :1

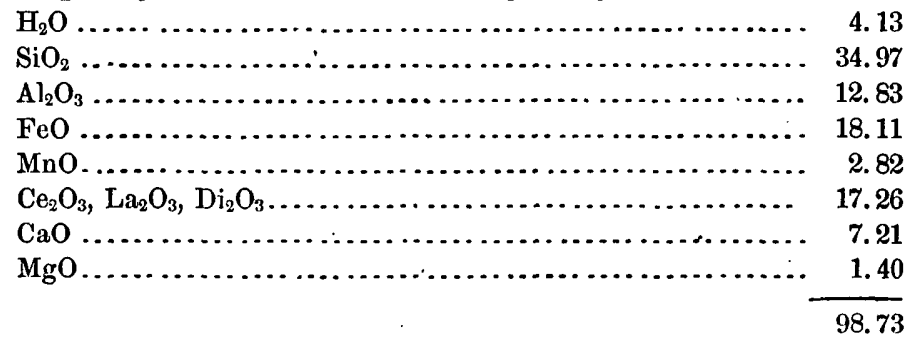

'Compare analysis by F. C. Robinson, Amer. Jour. Sci., May, 1884. 
The ferrous oxide carries with it some ferric oxide. As the analysis was made merely for the complete identification of the species, the troublesome separation of the cerium group oxides was not considered necessary. The mineral appears to vary considerably in different parts of the quarry.

BERYL FROM GREENE COUNTY, TENNESSEE.

A typical, bluish-green translucent beryl. Analysis by F. W. Clarke:

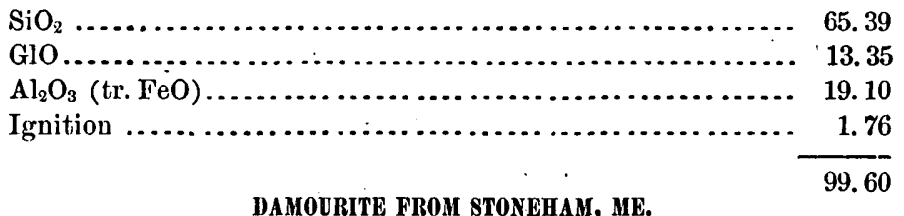

Two specimens of a micaceous mineral from the topaz locality at Stoneham, collected by Mr. N. H. Perry, of Sonth Paris, and sent by him to the National Museum, have been examined and prove to be different forms of damourite.

A. Subfibrous compact, light grayish green in color, greasy luster, associated with albite and topaz.

B. Broadly foliated micaceous, light grayish green, strong mother-ofpearl luster, also associated with topaz. Analyses (Chatard) as follows:

\begin{tabular}{|c|c|c|}
\hline & $A$. & $\boldsymbol{B}$. \\
\hline Ignition ........... & 4.48 & 4.78 \\
\hline $\mathrm{SiO}_{2} \ldots \ldots \ldots \ldots \ldots$ & 45.19 & 45.34 \\
\hline $\mathrm{Al}_{2} \mathrm{O}_{3} \ldots \ldots \ldots$ & 33. 32 & 33. 96 \\
\hline $\mathrm{FeO} \ldots \ldots \ldots \ldots$ & 4. 25 & 3.96 \\
\hline $\mathrm{MnO} \ldots \ldots \ldots \ldots \ldots \ldots$ & 0.58 & 0.51 \\
\hline $\mathrm{CaO} \ldots \ldots \ldots \ldots \ldots \ldots$ & trace. & 0.22 \\
\hline Mgo........................ & 0.36 & 0.10 \\
\hline $\mathrm{Na}_{2} \mathrm{O} \ldots \ldots \ldots \ldots \ldots$ & 1.57 & 1.49 \\
\hline \multirow[t]{2}{*}{$\mathrm{K}_{2} \mathrm{O} \ldots \ldots \ldots \ldots \ldots \ldots \ldots \ldots \ldots$} & 11.06 & 10.73 \\
\hline & 100.81 & 101.09 \\
\hline
\end{tabular}

MARGARITE.

A. From Soapstone Hill, near Gainesville, Georgia. Bright pistachio green, subfibrous aggregate of extremely minute scales surrounding and radiating from a core of bright rose-pink corundum which is in places interlaminated by the margarite. A very handsome specimen on account of the contrast of color. From Mr. Theodore Moreno, of Gainesville, Georgia. G. $=3.00 ;$ H. $=3.5$. Analysis (T. M. Chatard) :

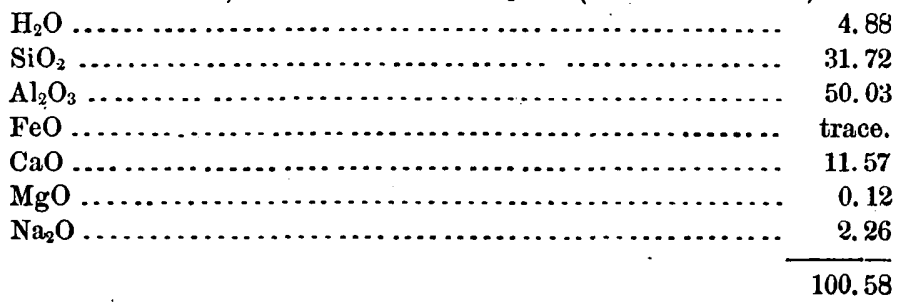


B. An altered crystal of corundum from Iredell County, North Caro. lina, showing a core of corundum surrounded by a yellowish-white, semimicaceons, compact mineral more or less intermixed with small needles of black tourmaline. Analysis (Chatard) shows the micaceous mineral to be a margarite similar to that described by Dr. F. A. Genth as occurring at Hendrick's farm in the same county.

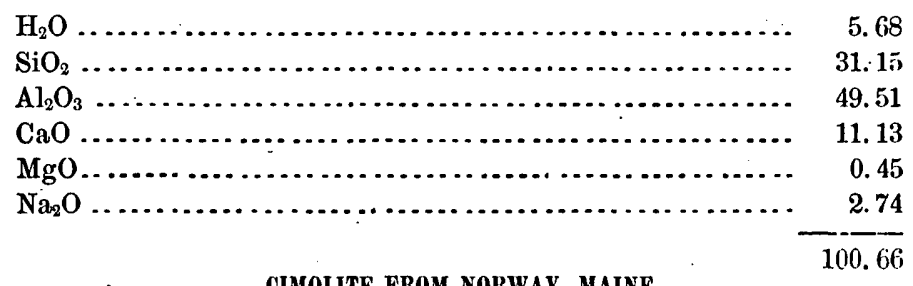

Among a collection of Maine minerals received from N. H. Perry, of South Paris, were several specimens of tourmaline and albite encrusted with a pink to rose-purple, earthy, alteration prodnct. The color was found to be due to a little manganese, which was not, however, separately estimated. The analysis (Clarke) gave results approaching to those required by the rational formula $\mathrm{AlH}_{3}\left(\mathrm{SiO}_{3}\right)_{3}$, as the subjoined figures show :

\begin{tabular}{|c|c|c|}
\hline & Found. & Theory. \\
\hline $\mathrm{H}_{2} \mathrm{O} \ldots$ & 9.53 & 10.4 \\
\hline $\mathrm{SiO}_{2} \ldots \ldots \ldots \ldots$ & 70.06 & 69.8 \\
\hline $\mathrm{Al}_{2} \mathrm{O}_{3}$ (with $\mathrm{MnO}$ ) & 17.19 & 19.8 \\
\hline $\mathrm{Na}_{2} \mathrm{O} \ldots \ldots \ldots \ldots$ & 2.28 & \\
\hline \multirow[t]{2}{*}{ 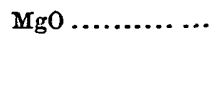 } & 0.80 & \\
\hline & 99.86 & 100.0 \\
\hline
\end{tabular}

It will be observed at once that these results do not agree exactly with those commonly obtained for cimolite. They are too high in silica, and too low in water, and the formula deduced from them is somewhat norel. We are inclined to place the mineral, however, under cimolite, as being nearer to that species than to any other. Possibly the new formula represents the final outcome of an alteration process which ordinary cimolite has only partially undergone. Somewhat similar pink alteration products are not uncommon in the albitic granite veins of Maine and New Hampshire, and some, without analysis, have been supposed to be montmorillonite, like that of Branchville, Connecticut. A more thorough examination of such products is much to be desired.

\section{HALLOYSITE FROM OALIFORNIA.}

Collected by Ensign J. B. Bernadou, at the Detroit Copper Mine, near Mono Lake. The specimens consisted of irregular lumps, covered and seamed with a black coating of the oxides of copper and manganese. 
The color of the pure mineral was white, with a very faint tinge of blue. Analysis by F. W. Clarke.

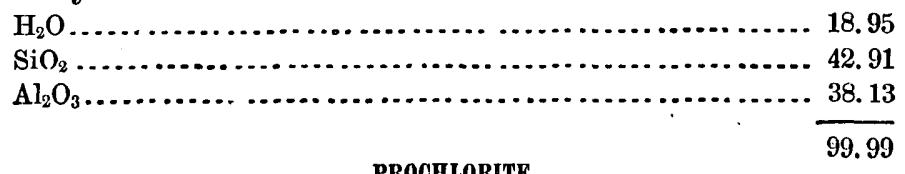

PROOHLORITE.

A dark-green chlorite, collected by Mr. G. P. Merrill on Foundry Run, Georgetown, D. C., may be assigned to the above-named species. The mineral is very dark in color, scaly-crystalline, and occurs in quite fine specimens. Analysis by F. W. Olarke.

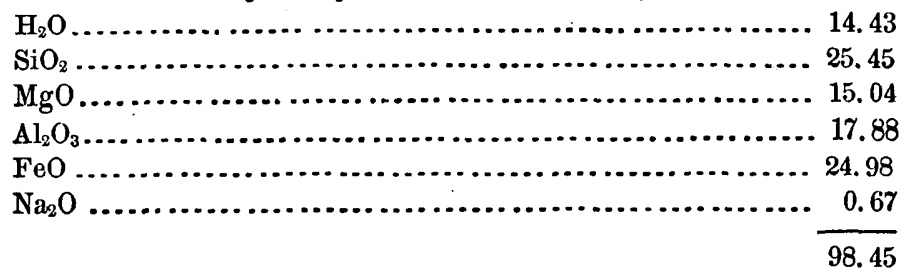

The iron is all reckoned as ferrous iron, although part of it is undoubt. edly ferric.

SO-CALLED "ALUM ROOK" FROM GRANT COUNTY, NEW MEXICO.

Six samples were received from Hon. W. S. Rosecrans. The material is found at the headwaters of the Gila River, about 40 miles north of Silver City, and is said to cover about 2,000 acres. The specimens may be described as follows:
A. Pinkish crusts.
B. Yellowish crusts.
C. Drab crusts.
D. White crusts.
E. Fibrous mineral of silky luster.
F. "Gray alum rock."
Analyses by F. W. Clarke.

A.

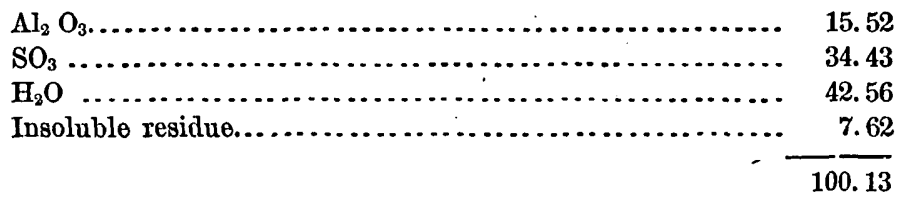

This substance is alunogen. So, also, but impure, containing iron, are $\mathrm{B}, \mathrm{C}$, and $\mathrm{D}$. Of these only rough analyses were made.

\begin{tabular}{|c|c|c|c|}
\hline & B. & c. & D. \\
\hline Ignition ..................... & 16.20 & 71. 28 & 55.41 \\
\hline $\mathrm{Al}_{2} \mathrm{O}_{3}+\mathrm{Fe}_{2} \mathrm{O}_{3} \ldots \ldots \ldots \ldots$ & 4.95 & 15.81 & 9.19 \\
\hline \multirow[t]{2}{*}{ Insoluble residuo ....... } & 78.95 & 12.27 & 33. 19 \\
\hline & 100.10 & 89.36 & 97.78 \\
\hline
\end{tabular}


The analysis of $\mathrm{E}$ shows it to be halotrichite. Only a trane of ferric iron is present. Color nearly white, slightly grayish. Asbestiform.

E.

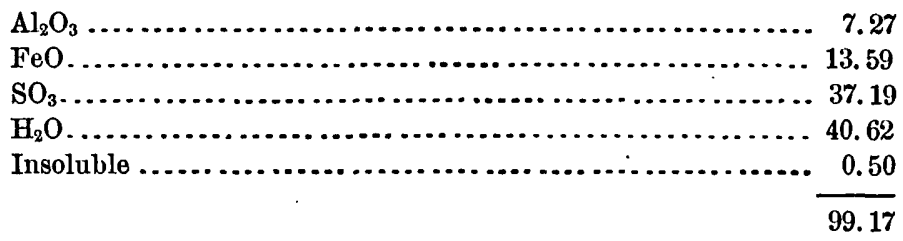

F, which was not analyzed, is merely an impure mixture of alunogen and halotrichite.

SCORIACEOUS OBSIDIAN, SOUTHEAST BIDE OW MONO VALLEY, CALIFORNIA.

A grayish-white rock which forms a large portion of the Mono craters. Collected by I. C. Russell. Analysis by T. M. Chatard.

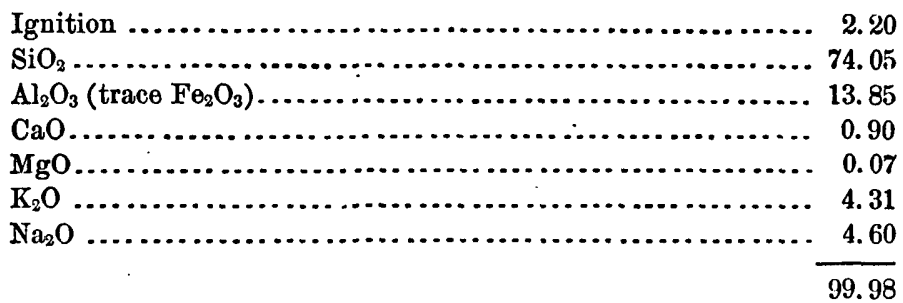

WHITE POWDER FROṀ LAHONTAN LAKE-BEDS, TRUCKEE RIVER.

A volcanic dust which fell in the quaternary Lake Lahontan. Supposed to have been erupted from the Mono craters. Collected by I. C. Russell. Analysis by T. M. Chatard.

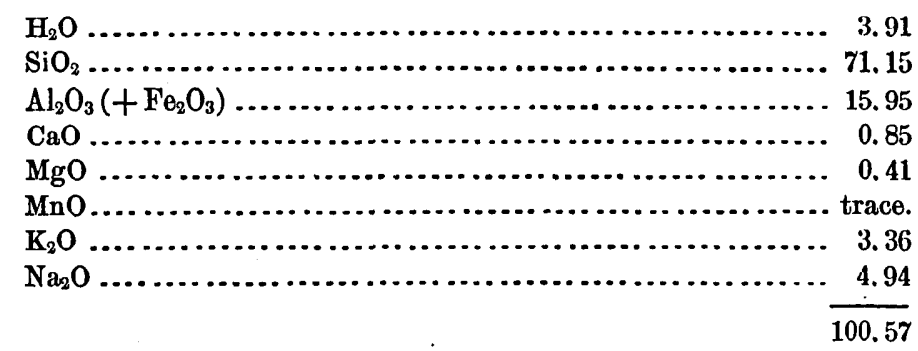

MARL FROM “WHITE TERRACE," 3 MLLES WEST OF MULLEN'S SPRINGS, WEST SHORE OF PYRA. MID LAKE, NEVADA.

Mostly deposited from the waters of the prehistoric Lake Lahontan. Collected by I. C. Russell. Analysis by T. M. Chatard.

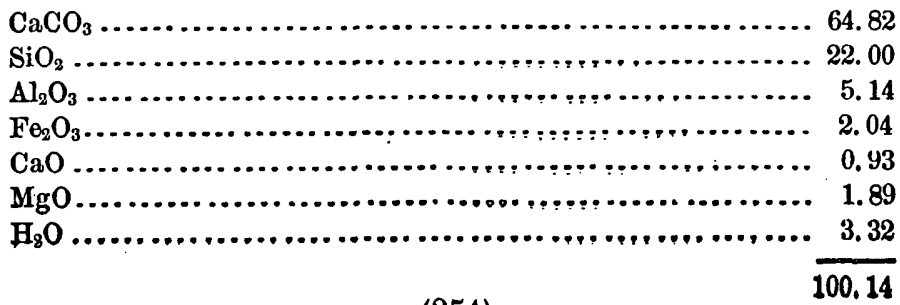


TWO CLATS FROM HUMBOLDT RIVER BRIDGE, MLL GITY, NEVADA.

A. From Upper Lahontan Lake-beds. B. From Lower Lahontan Lake-beds. Collected by I. C. Russell. Analyzed by T. M. Chatard. Color in both cases grayish.

\begin{tabular}{|c|c|c|}
\hline & A. & B. \\
\hline Ignition ... & 0.78 & 13.03 \\
\hline $\mathrm{SiO}_{2} \ldots \ldots \ldots \ldots$ & 56. 30 & 50.70 \\
\hline $\mathrm{Al}_{2} \mathrm{O}_{3} \ldots \ldots \ldots$ & 16.52 & $* 19.01$ \\
\hline $\mathrm{Fe}_{2} \mathrm{O}_{3} \ldots \ldots \ldots$ & 5.08 & …...... \\
\hline $\mathrm{CaO} \ldots \ldots \ldots \ldots$ & 5.45 & 10.26 \\
\hline MgO.......... & 2.64 & 3. 19 \\
\hline $\mathrm{K}_{2} \mathrm{O} \ldots \ldots \ldots$ & 2.17 & 2.16 \\
\hline \multirow[t]{2}{*}{$\mathrm{Na}_{2} \mathrm{O} \ldots \ldots \ldots$} & 2.60 & 1.91 \\
\hline & 100.54 & 100.26 \\
\hline
\end{tabular}

* With a little $\mathrm{Fe}_{2} \mathrm{O}_{3}$.

\section{BASALT FROM MOUNT THIELSON, OREGON.}

Material collected by J. S. Diller; by whom also the lithological separations were made. Analyses of rock and component parts as follows :

A. Basalt. F. W. Clarke.

B. Groundmass. T. M. Chatard.

C. Hypersthene. T. M. Chatard.

D. Feldspar, specific gravity, 2.637-2.714. T. M. Chatard.

E. Feldspar, specific gravity, 2.714-2.877. T. M. Chatard.

\begin{tabular}{|c|c|c|c|c|c|}
\hline & A. & B. & C. & D. & E. \\
\hline 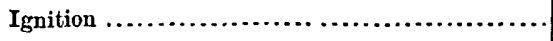 & .60 & .52 & …..... & .40 & .66 \\
\hline 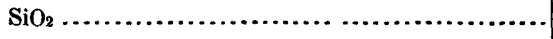 & 55.68 & 53.85 & 53. 31 & . 51.95 & 55.48 \\
\hline 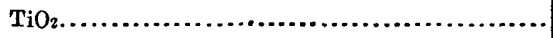 & undet. & ........... & ........ & trace. & .30 \\
\hline 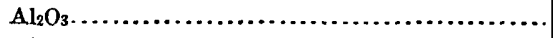 & 18.93 & 22.95 & 5.99 & 28.84 & 26. 91 \\
\hline 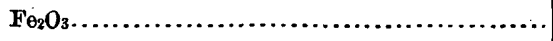 & 8.73 & 4. 59 & $s \cdots \cdots \cdot$ & 2.24 & 2.32 \\
\hline FeO & $\xi$ & 4. 30 & 13.43 & ........... & ...... \\
\hline 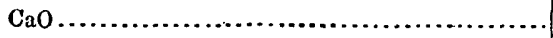 & 7.99 & 8.41 & 3. 69 & 11.42 & 8.11 \\
\hline MgO .................................. & 4. 86 & 3.08 & 21.69 & 1.34 & 2. 27 \\
\hline 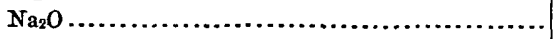 & 2.12 & 2.16 & & 3. 22 & 3.14 \\
\hline \multirow[t]{2}{*}{ 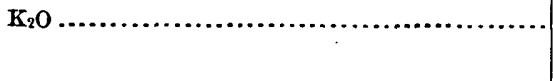 } & .48 & 2.67 & ............ & .59 & .72 \\
\hline & 99. 39 & 100.23 & 98.11 & 100.00 & 100.00 \\
\hline
\end{tabular}

In $\mathrm{B}$ a trace of $\mathrm{P}_{2} \mathrm{O}_{5}$ was found, and in $\mathrm{C}$ a trace of manganese. $\mathrm{D}$ and $\mathrm{E}$ are near labradorite, and are evidently mixtures. $\mathrm{C}, \mathrm{D}$, and $\mathrm{E}$ were received in very small quantities; not sufficient for full analysis. $\mathrm{D}$ and $\mathrm{E}$ therefore were treated with hydrofluoric acid, in order to render possible the estimation of the alkalies, and silica was taken by difference, 
Less than half a gramme of a fulgurite, formed by the fusion of this basalt by lightning, was also partially analyzed. The results (Clarke) are as follows:

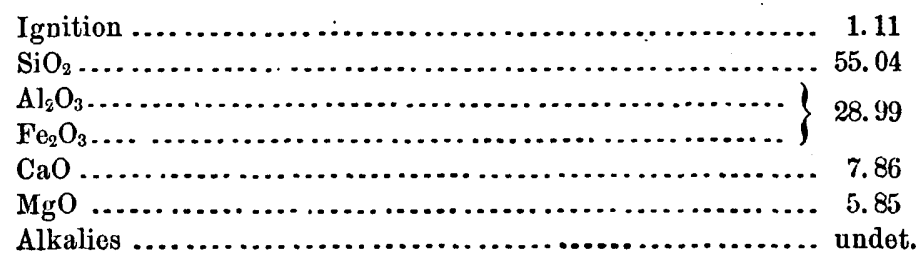

98.85

BASALT FROM PIT RIVER, NORTI OF BURNEY VALLEY, CALIFORNIA.

Collected by J. S. Diller. Analysis by F. W. Clarke.

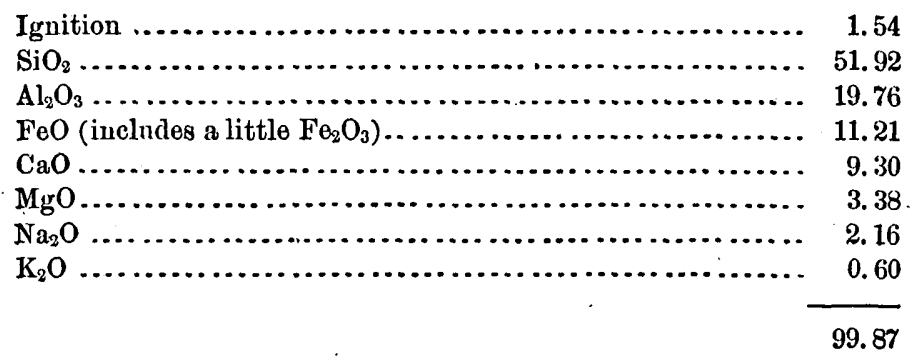

DACITES FROM LASSEN'S PEAK, CALIFORNIA.

Collected by J. S. Diller. Analyses by T. M. Chatard.

A. Gray dacite.

B. Reddish dacite.

C. Inclusion in dacite.

\begin{tabular}{|c|c|c|c|}
\hline & A. & B. & C. \\
\hline Ignition ................. & 0.56 & 0.44 & 1.35 \\
\hline $\mathrm{SiO}_{2} \ldots \ldots \ldots \ldots \ldots \ldots$ & 69.51 & 68.20 & 58.97 \\
\hline $\mathrm{Al}_{2} \mathrm{O}_{3} \ldots \ldots \ldots \ldots \ldots$ & 15.75 & 16.98 & 18.60 \\
\hline $\mathrm{Fe}_{e_{2} \mathrm{O}_{3}} \ldots \ldots \ldots \ldots \ldots$ & 3.34 & 3.75 & 5.94 \\
\hline $\mathrm{CaO}$ & 1.71 & 4.33 & 2.84 \\
\hline $\mathrm{MgO} . . . . . . . . . . .$. & 2.09 & 2.07 & 6.89 \\
\hline $\mathrm{Na}_{2} \mathrm{O} \ldots \ldots \ldots \ldots \ldots$ & 3.89 & 2.98 & 3. 05 \\
\hline $\mathrm{K}_{2} \mathrm{O} \ldots \ldots \ldots \ldots \ldots$ & 3.34 & 1.52 & 2.24 \\
\hline \multirow[t]{2}{*}{$\mathrm{P}_{2} \mathrm{O}_{6} \ldots \ldots \ldots \ldots$} & trace & a......... & undet. \\
\hline & 100.19 & 100.27 & 99.88 \\
\hline
\end{tabular}


Clarke and chatard.] MINERAL, ROCK, AND ORE ANALYSEE.

TWO SAMPLES OF LIMESTONE FROM MOUNDSVILLE NARROWS, TWELVE MILES BELOW WHEELINQ, W. VA.

A. Upper ledge. B. Lower ledge. Analyses by T. M. Chatard.

\begin{tabular}{|c|c|c|}
\hline & A. & B. \\
\hline Moisture ............... & 0.05 & 0.10 \\
\hline Insoluble............... & 10.33 & 1.53 \\
\hline $\mathrm{CO}_{2} \ldots \ldots \ldots \ldots \ldots \ldots$ & 39.18 & 43. 16 \\
\hline $\mathrm{CaO} \ldots \ldots \ldots \ldots \ldots$ & 48.02 & 53.26 \\
\hline MgO................... & 1.08 & 0.93 \\
\hline $\mathrm{Fe}_{2} \mathrm{O}_{3} \ldots \ldots \ldots \ldots \ldots \ldots$ & 0.90 & 0.96 \\
\hline \multirow[t]{2}{*}{$\mathrm{MnO}$ and $\mathrm{P}_{2} \mathrm{O}_{5} \ldots \ldots \ldots$} & traces & traces \\
\hline & 99.56 & 99. 94 \\
\hline
\end{tabular}

EQUIVALENT TO-

\begin{tabular}{|c|c|c|}
\hline Moisture.............. & 0.05 & 0.10 \\
\hline $\mathrm{CaCO}_{3} \ldots \ldots \ldots \ldots$ & 85.75 & 95.10 \\
\hline $\mathrm{MgCO}_{3} \ldots \ldots \ldots \ldots \ldots$ & 2.26 & 1.95 \\
\hline $\mathrm{FeCO}_{3} \ldots \ldots \ldots \ldots$ & 0.73 & 0.79 \\
\hline \multirow[t]{2}{*}{ Sand, clay, and $\mathrm{Fe}_{2} \mathrm{O}_{3}}$. & 10.77 & 2. 00 \\
\hline & 99.56 & 99.94 \\
\hline
\end{tabular}

MAGNETIC IRON ORE FROM NEAR BOZEMAN, MONTANA.

Found in the Gallatin Range, between Middle and Bozeman Creeks, sonthwest of Bozeman.

Received from A. C. Peale. Analysis by T. M. Chatard.

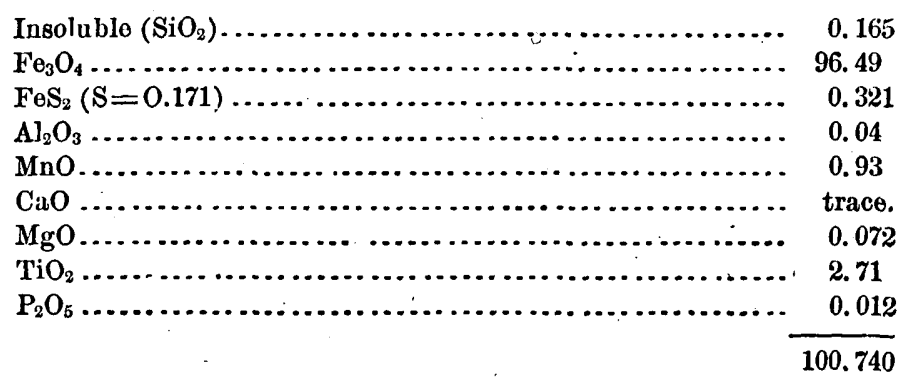

The titanium was determined in a separate portion, and is probably ligh from presence of iron.

Bull. 9-2 
LIMONITE FRON OANAAN MT., TUCKER OOUNTY, W. VA.

Analysis by T. M. Chatard.

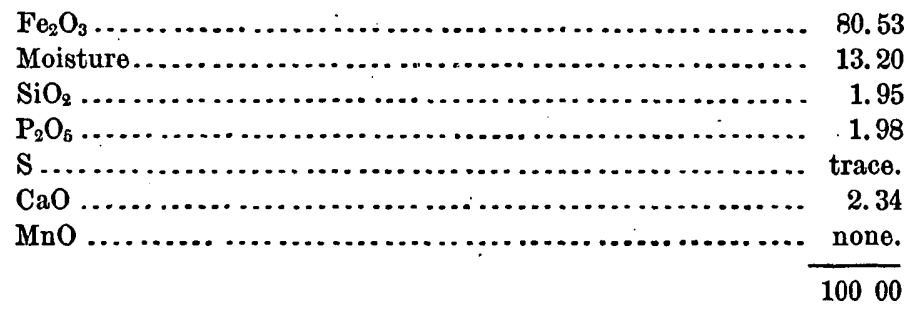

COAL FROM OBANSTON, R. I.

Analysis by F. A. Gooch. Specific gravity, 2.209 at 150.

Water .......................................... 0.24

Volatile matter $\ldots \ldots \ldots \ldots \ldots \ldots \ldots \ldots \ldots \ldots \ldots \ldots \ldots \ldots, \quad 4.49$

Fixed carbon ..................................... 82.20

Ash ............................................. 13.07

100.00

Sulphur ......................................... 0.34

(258) 


\section{WATER ANAL YSES.}

With the exceptions of the waters from Montana, the Utảh Hot Springs, and the Virginia Hot Springs, the following waters were collected by the Division of the Great Basin, under the direction of Messrs. G. K. Gilbert and I. C. Russell. For sufficient reasons, it was necessary to abbreviate the analyses as much as possible, and this was done by avoiding the direct estimation of carbonic acid. Whenever carbonates were proved to be present all the other ingredients of a water were determined and the carbonic acid, reckoned as $\mathrm{CO}_{3}$, was taken as the difference between the sum of their weights and the weight of the total solid residue. In computing the probable compounds formed by the union of acids and bases, the chlorides and sulphates were first disposed of, and the bases in excess were then calculated as carbonates. This procedure gave usually a summation a little greater or less than the total solids directly found upon evaporating the water to dryness; and the variation of the result from 100 per cent. afforded a means of estimating the probable accuracy of the analysis. In most cases the samples of water received were insufficient for a search after the less common elements. These, therefore, were necessarily ignored, except in so far as the spectroscope or qualitative tests could reveal their presence. The gaseous contents of the waters received no consideration. In certain respects, therefore, all the analyses are to be regarded as imperfect; although they are fully adequate for the geological purposes which led to their being made.

Each analysis is stated in three columns. First, the actual weight in grammes to the liter of each constituent. Second, the percentage of each relatively to the total solid residue. Third, the probable combination, also in grammes to the liter. The second column gives a means of comparing different waters as to their composition, irrespective of their greater or less salinity. The third column was computed in the simplest terms, and not with reference to complex and doubtful hypoth. eses.

PYRAMID LAKE, NEVADA.

Four samples of water were analyzed (Clarke), as follows :

A. Water of north end of the lake, near the surface.

B. Water of north end of the lake, depth of 108 meters.

C. Water of south end of the lake, near the surface.

D. Water of south end of the lake, depth of 61 meters.

All four samples contained suspended flakes of silicious and calcareous matter. 
A.

['Total solids, 3.4987 grammes to liter.]

\begin{tabular}{|c|c|c|c|}
\hline \multicolumn{2}{|l|}{ Found. } & \multirow{2}{*}{$\frac{\begin{array}{c}\text { Per cent. } \\
\text { of total } \\
\text { solids. }\end{array}}{1.17}$} & Probablo combination. \\
\hline $\mathrm{SiO}_{2} \ldots \ldots \ldots$ & 0.0412 & & $\mathrm{SiO}_{2} \ldots \ldots \ldots \ldots \ldots . \ldots . \ldots 412$ \\
\hline $\mathrm{SO}_{4} \ldots \ldots \ldots$ & 0.1803 & 5.15 & KCl ............ 0.1474 \\
\hline $\mathbf{C l} \ldots \ldots \ldots$ & 1. 4298 & 40.87 & $\mathrm{NaCl} \ldots \ldots \ldots \ldots \ldots .2 .2411$ \\
\hline $\mathrm{Ca} . . . \ldots \ldots$ & 0.0179 & 0.51 & $\mathrm{Na}_{2} \mathrm{SO}_{4} \ldots \ldots \ldots \ldots \ldots . \quad 0.2667$ \\
\hline $\mathbf{M g} \ldots \ldots \ldots$ & 0.0800 & 2.29 & $\mathrm{Na}_{2} \mathrm{CO}_{3} \ldots \ldots \ldots \ldots . \quad 0.4738$ \\
\hline $\mathrm{Na} . . . \ldots \ldots$ & 1. 1731 & 33.53 & $\mathrm{CaCO}_{3} \ldots \ldots \ldots \ldots \ldots .0 .0447^{\circ}$ \\
\hline \multirow[t]{2}{*}{$\mathbf{K} \ldots \ldots \ldots$} & 0.0766 & 2.19 & $\mathrm{MgCO}_{3} \ldots \ldots \ldots \ldots . . .2800$ \\
\hline & 2.9989 & & 3.4949 \\
\hline \multirow{2}{*}{$\mathrm{CO}_{3} \ldots \ldots \ldots$} & 0.4998 & 14.29 & \multirow[t]{2}{*}{99.94 per cent. accounted for. } \\
\hline & 3.4987 & 100.00 . & \\
\hline
\end{tabular}

B.

[Total solids: 3.4837 grammes to liter.].

\begin{tabular}{|c|c|c|c|}
\hline \multicolumn{2}{|l|}{ Foúnd. } & \multirow{2}{*}{$\begin{array}{c}\begin{array}{c}\text { Per cent. } \\
\text { of total } \\
\text { solids. }\end{array} \\
0.57\end{array}$} & Probable combination. \\
\hline $\mathrm{SiO}_{2} \ldots \ldots \ldots$ & 0.0200 & & $\mathrm{SiO}_{2} \ldots \ldots \ldots \ldots \ldots \ldots$ \\
\hline $\mathrm{SO}_{4} \ldots \ldots \ldots$ & 0.1850 & 5.31 & KCl ............. 0.1381 \\
\hline Cl .......... & 1.4342 & 41. 17 & $\mathrm{NaCl} \ldots \ldots \ldots \ldots \ldots . .2 .2550$ \\
\hline $\mathrm{Ca} \ldots \ldots \ldots$ & 0.0179 & 0.51 & $\mathrm{Na}_{2} \mathrm{SO}_{4} \ldots \ldots \ldots \ldots \ldots . . .2737$ \\
\hline $\mathbf{M g} \ldots . . . .$. & 0.0805 & 2.31 & $\mathrm{Na}_{2} \mathrm{CO}_{3} \ldots \ldots \ldots \ldots . .4756$ \\
\hline $\mathbf{N a} \ldots \ldots \ldots$ & 1. 1817 & 33.92 & $\mathrm{CaCO}_{3} \ldots \ldots \ldots \ldots \ldots \ldots$ \\
\hline \multirow[t]{2}{*}{$\mathbf{K} \ldots \ldots \ldots \ldots$} & 0.0723 & 2.07 & $\mathrm{MgCO}_{3} \ldots \ldots \ldots \ldots$ \\
\hline & 2. 9916 & & 3.4889 \\
\hline \multirow[t]{2}{*}{$\mathrm{CO}_{3} \ldots \ldots \ldots$} & 0.4921 & 14.14 & \multirow[t]{2}{*}{ Total; 100.15 per cent. } \\
\hline & 3. 4837 & 100.00 & \\
\hline
\end{tabular}

C.

[Total solids: 3.4725 grammes to liter.]

\begin{tabular}{|c|c|c|c|}
\hline Found. & . & $\begin{array}{c}\text { Per cent. } \\
\text { of total } \\
\text { solids. }\end{array}$ & Probable combiuation. \\
\hline $\mathrm{SiO}_{2} \ldots \ldots \ldots$ & 0.0425 & 1. 22 & $\mathrm{SiO}_{2} \ldots \ldots \ldots \ldots \ldots \ldots, 0.0425$ \\
\hline $\mathrm{SO}_{4} \ldots \ldots \ldots$ & 0.1772 & 5.10 & KCl............. 0.1374 \\
\hline Cl ........... & 1.4288 & 41.15 & $\mathrm{NaCl} \ldots \ldots \ldots \ldots \ldots 2.2466$ \\
\hline $\mathrm{Ca} \ldots \ldots \ldots$ & $\ldots \ldots \ldots$ & $\ldots \ldots \ldots \ldots$ & $\mathrm{Na}_{2} \mathrm{SO}_{4} \ldots \ldots \ldots \ldots \ldots \ldots .6 .2621$ \\
\hline $\mathbf{M g} \ldots \ldots \ldots$ & 0.0752 & 2.17 & $\mathrm{Na}_{2} \mathrm{CO}_{3} \ldots \ldots \ldots \ldots . . .6 .4940$ \\
\hline Na ........... & 1.1826 & 34.06 & $\mathrm{CaCO}_{3} \ldots \ldots \ldots \ldots \ldots \ldots \ldots$ \\
\hline K.... & 0.0719 & 2.07 & $\mathrm{MgCO}_{3} \ldots \ldots \ldots \ldots . . .6 .2632$ \\
\hline . & 2.9782 & & 3.4458 \\
\hline \multirow[t]{2}{*}{$\mathrm{CO}_{3} \ldots \ldots \ldots$} & 0.4943 & 14. 23 & \multirow[t]{2}{*}{99.23 per cent. accounted for. } \\
\hline & 3.4725 & 100.00 & \\
\hline
\end{tabular}


D.

[Total solids: 3.4900 grammes to liter.]

\begin{tabular}{|c|c|c|c|}
\hline \multicolumn{2}{|l|}{ Found. } & $\begin{array}{l}\text { Percent. } \\
\text { of total } \\
\text { solids. }\end{array}$ & $\begin{array}{l}\text { Probable combination. } \\
\text {. }\end{array}$ \\
\hline $\mathrm{SiO}_{2} \ldots \ldots \ldots$ & 0.0300 & 0.86 & $\mathrm{SiO}_{2} \ldots \ldots \ldots \ldots \ldots \ldots 0.0 . \ldots 00$ \\
\hline $\mathrm{SO}_{4} \ldots \ldots \ldots$ & 0.1864 & 5.34 & 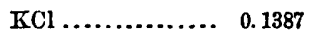 \\
\hline $\mathrm{Cl} \ldots \ldots \ldots$ & 1. 4271 & 40.99 & $\mathrm{NaCl} \ldots \ldots \ldots \ldots \ldots . .2428$ \\
\hline $\mathrm{Ca} \ldots \ldots \ldots \ldots$ & & 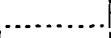 & $\mathrm{Na}_{2} \mathrm{SO}_{4} \ldots \ldots \ldots \ldots \ldots . . . \quad 0.2757$ \\
\hline Mg .......... & 0.0832 & 2.38 & $\mathrm{Na}_{2} \mathrm{CO}_{3} \ldots \ldots \ldots \ldots . . .4834$ \\
\hline $\mathrm{Na} . . . . . . .$. & 1.1809 & 33.84 & $\mathrm{CaCO}_{3} \ldots \ldots \ldots \ldots \ldots \ldots \ldots$ \\
\hline \multirow[t]{2}{*}{$\mathbf{K} \ldots \ldots \ldots$} & 0.0726 & \multirow[t]{2}{*}{2.13} & $\mathrm{MgCO}_{3} \ldots \ldots \ldots \ldots \ldots$ \\
\hline & 2.9802 & & 3. 4618 \\
\hline \multirow[t]{2}{*}{$\mathrm{CO}_{3} \ldots \ldots \ldots$} & 0.5098 & 14.46 & \multirow[t]{2}{*}{09.19 per cent. accounted for. } \\
\hline & 3.4900 & 100.00 & \\
\hline
\end{tabular}

The slight differences between these analyses may be attributed in part to the fact that the lake is fed at its southern end by a large stream of fresh water. The four percentage columns may be conveniently com. pared in the following table:

\begin{tabular}{|c|c|c|c|c|}
\hline & A. & B. & C. & D. \\
\hline \multirow{2}{*}{$\begin{array}{l}\text { Total solids...... } \\
\mathrm{SiO}_{2} \ldots \ldots \ldots \ldots \ldots\end{array}$} & 3. 4987 & 3. 4837 & 3.4725 & 3.4900 \\
\hline & 1.17 & 0.57 & 1.22 & 0.86 \\
\hline $\mathrm{SO}_{4} \ldots \ldots \ldots \ldots \ldots$ & 5.15 & 5.31 & 5.10 & 5.34 \\
\hline $\mathrm{Cl} \ldots \ldots \ldots \ldots \ldots$ & 40.87 & 41.17 & 41.15 & 40.99 \\
\hline $\mathrm{Ca} \ldots \ldots \ldots$ & 0.51 & 0.51 & ............ & …...... \\
\hline $\mathrm{Mg} . . . \ldots \ldots \ldots$ & 2.29 & 2.31 & 2.17 & 2.38 \\
\hline $\mathrm{Na} . . . . . . . . .$. & 33.53 & 33.92 & 34.06 & 33.84 \\
\hline K................. & 2.19 & 2:07 & 2.07 & 2.13 \\
\hline \multirow[t]{2}{*}{$\mathrm{CO}_{3} \ldots \ldots . . . . . .}$. & 14.29 & 14.14 & 14.23 & 14.46 \\
\hline & 100.00 & 100.00 & 100.00 & 100.00 \\
\hline
\end{tabular}

WINNEMUCCA LAKE, NEVADA.

Specific gravity of water, 1.001, at 17\%. Analysis by F. W. Clarke.

[Total solids: 3.6025 grammes to liter.]

\begin{tabular}{|c|c|c|c|}
\hline \multicolumn{2}{|l|}{ Found. } & \multirow{2}{*}{$\begin{array}{c}\begin{array}{c}\text { Per cent. } \\
\text { of total } \\
\text { solids. }\end{array} \\
0.76\end{array}$} & Probable combination. \\
\hline $\mathrm{SiO}_{2} \ldots \ldots \ldots$ & 0.0275 & & $\mathrm{SiO}_{2} \ldots \ldots \ldots \ldots \ldots \ldots \quad 0.0275$ \\
\hline $\mathrm{SO}_{4} \ldots \ldots \ldots \ldots$ & 0.1333 & 3. 70 & KCl $\ldots \ldots \ldots \ldots \ldots \ldots$ \\
\hline $\mathrm{Cl} \ldots \ldots \ldots$ & 1. 6934 & 47.01 & $\mathrm{NaCl} \ldots \ldots \ldots \ldots \ldots . . .6877$ \\
\hline Ca............. & 0.0196 & 0.54 & $\mathrm{Na}_{2} \mathrm{SO}_{4} \ldots \ldots \ldots \ldots \ldots$ \\
\hline $\mathbf{M g} \ldots$ & 0.0173 & 0.48 & $\mathrm{Na}_{2} \mathrm{CO}_{3} \ldots \ldots \ldots \ldots \ldots$ \\
\hline $\mathrm{Na} . . . . . . .$. & 1.2970 & 36.00 & $\mathrm{CaCO}_{3} \ldots \ldots \ldots \ldots$ \\
\hline \multirow[t]{2}{*}{$\mathbf{K} \ldots \ldots \ldots$} & 0.0686 & 1.90 & $\mathrm{MgCO}_{3} \ldots \ldots \ldots \ldots . . . . . .0494$ \\
\hline & 3.2567 & & 3. 5247 \\
\hline \multirow[t]{2}{*}{$\mathrm{CO}_{3} \ldots \ldots \ldots$} & 0.3458 & 9.61 & \multirow[t]{2}{*}{98.44 per cent. acconnted for. } \\
\hline & 3.6025 & 100.00 & \\
\hline
\end{tabular}


WALKER LAKE, NEVADA.

Two analyses (Clarke) were made; one of a sample taken just below the surface, the other of water from a depth of 65.5 meters. Both were collected by Mr. I. C. Russell.

$$
\text { A.-Surface 8ample. }
$$

[Total solids : 2.5155 grammes to the liter.]

\begin{tabular}{|c|c|c|c|}
\hline \multicolumn{2}{|l|}{ Found. } & \multirow{2}{*}{$\begin{array}{c}\begin{array}{c}\text { Per cent. } \\
\text { of total } \\
\text { solids. }\end{array} \\
0.29\end{array}$} & Probable combination. \\
\hline $\mathrm{SiO}_{2} \ldots \ldots \ldots$ & 0.0075 & & $\mathrm{SiO}_{2} \ldots \ldots \ldots \ldots \ldots . . .0 .0075$ \\
\hline $\mathrm{SO}_{4} \ldots \ldots \ldots \ldots$ & 0.5275 & 20.96 & $\mathrm{NaCl} \ldots \ldots \ldots \ldots \ldots . . .60681$ \\
\hline $\mathrm{Cl} \ldots \ldots \ldots \ldots$ & 0.5875 & 23.36 & $\mathrm{Na}_{2} \mathrm{SO}_{4} \ldots \ldots \ldots \ldots . \quad 0.7803$ \\
\hline $\mathrm{Ca} . . . \ldots . . . .$. & 0.0267 & 1.06 & $\mathrm{Na}_{2} \mathrm{CO}_{3} \ldots \ldots \ldots \ldots . . .60 .5157$ \\
\hline $\mathrm{Mg} \ldots \ldots \ldots$. & 0.0391 & 1.55 & $\mathrm{CaCO}_{3} \ldots \ldots \ldots \ldots \ldots .0 .0607$ \\
\hline $\mathrm{Na} . . . . . . .$. & 0.8577 & 34.11 & $\mathrm{MgCO}_{3} \ldots \ldots, \ldots \ldots .0 .1369$ \\
\hline $\mathbf{K} . .$. & trace. & & 2.4752 \\
\hline & 2.0460 & & 08.39 per cent. accounted for. \\
\hline $\mathrm{CO}_{3} \ldots \ldots \ldots . .$. & 0.4695 & 18.67 & \\
\hline & 2.5155 & 100.00 & \\
\hline
\end{tabular}

$$
\text { B.-Lower sample. }
$$

\begin{tabular}{|c|c|c|c|}
\hline \multicolumn{2}{|l|}{ Found. } & \multirow{2}{*}{$\begin{array}{c}\begin{array}{c}\text { Per cent. } \\
\text { of total } \\
\text { solids. }\end{array} \\
.30\end{array}$} & Probable combination. \\
\hline $\mathrm{SiO}_{2} \ldots \ldots \ldots$ & 0.0075 & & $\mathrm{SiO}_{2} \ldots \ldots \ldots \ldots \ldots \ldots .0 .0075$ \\
\hline $\mathrm{SO}_{4} \ldots \ldots \ldots \ldots$ & 0.5125 & 20.60 & $\mathrm{NaCl} \ldots \ldots \ldots \ldots \ldots . .0 .9558$ \\
\hline C] $\ldots \ldots \ldots \ldots$ & 0.5800 & 23. 32 & $\mathrm{Na}_{2} \mathrm{SO}_{4} \ldots \ldots \ldots \ldots \ldots . \quad 0.7580$ \\
\hline $\mathrm{Ca} \ldots \ldots \ldots \ldots$...... & 0.0176 & .71 & $\mathrm{Na}_{2} \mathrm{CO}_{3} \ldots \ldots \ldots \ldots .0 .5339$ \\
\hline $\mathbf{M g} \ldots \ldots \ldots$ & 0.0375 & 1.51 & $\mathrm{CaCO}_{3} \ldots \ldots \ldots \ldots . \quad 0.0440$ \\
\hline Na.......... & 0.8530 & 34.29 & $\mathrm{MgCO}_{3} \ldots \ldots \ldots \ldots . \quad 0.1313$ \\
\hline \multirow[t]{2}{*}{ K........... } & trace. & & 2.4305 \\
\hline & 2.0081 & & 97.66 per cent. accounted for. \\
\hline \multirow[t]{2}{*}{$\mathrm{CO}_{3} \ldots \ldots \ldots$} & 0.4794 & 19.27 & \\
\hline & 2.4875 & 100.00 & - \\
\hline
\end{tabular}

[Total solids: 2.4875 grammes to the liter.]

Mud taken from the bottom of the Lake, at a depth of 68 meters, was also examined qualitatively by Dr. Chatard. The portion soluble in water contained chlorides of sodium and potassium, with some sulphates and traces of borates. The residue, extracted with hydrochloric acid, was found to contain carbonates of lime and magnesia, with some phosphates, iron, alumina, and alkalies. The insoluble portion was impure silica. 
WALKER RIVER, NEVADA.

The sample of water was collected immediately below the junction or the east and west branches. Analysis by F. W. Clarke.

[Total solids : 0.1800 grammes to the liter.]

\begin{tabular}{|c|c|c|c|}
\hline \multicolumn{2}{|l|}{ Found. } & \multirow{2}{*}{$\frac{\begin{array}{c}\text { Per cent. } \\
\text { of total } \\
\text { solids. }\end{array}}{12.50}$} & Probable combination. \\
\hline $\mathrm{SiO}_{2} \ldots \ldots \ldots$ & .0225 & & $\mathrm{SiO}_{2} \ldots \ldots \ldots \ldots \ldots \ldots .0 .0225$ \\
\hline $\mathrm{SO}_{4} \ldots \ldots \ldots$. & .0284 & 15. 77 & $\mathrm{NaCl} \ldots \ldots \ldots \ldots \ldots .0 .0216$ \\
\hline Cl $\ldots \ldots \ldots$. & .0131 & 7.28 & $\mathrm{Na}_{2} \mathrm{SO}_{4} \ldots \ldots \ldots \ldots . . .0 .0421$ \\
\hline $\mathrm{Ca} \ldots . . \ldots \ldots$ & .0228 & 12.66 & $\mathrm{Na}_{2} \mathrm{CO}_{3} \ldots \ldots \ldots \ldots . . .0 .0224$ \\
\hline $\mathrm{Mg} \ldots \ldots \ldots$. & .0038 & 2.12 & $\mathrm{CaCO}_{3} \ldots \ldots \ldots \ldots \ldots . . .0570$ \\
\hline $\mathrm{Na} . . . \ldots . . .$. & .0318 & 17.67 & $\mathrm{MgCO}_{3} \ldots \ldots \ldots \ldots . .0 .0133$ \\
\hline \multirow{3}{*}{$\mathrm{CO}_{3} \ldots \ldots \ldots$} & .1224 & & 0.1789 \\
\hline & .0576 & 32.00 & \multirow[t]{2}{*}{ 99.39 per cent. accounted for. } \\
\hline & .1800 & 100.00 & \\
\hline
\end{tabular}

HUMBOLDT RIVER, NEVADA.

Sample collected at Stone House. Analysis by T. M. Chatard.

[Total solids : 0.3615 grammes to the liter.]

\begin{tabular}{|c|c|c|c|c|}
\hline Found. & & Per cent. & \multicolumn{2}{|c|}{ Probable combination. } \\
\hline $\mathrm{SiO}_{2} \ldots \ldots \ldots$ & .0326 & 9.03 & $\mathrm{SiO}_{2} \ldots \ldots \ldots \ldots$ & .0326 \\
\hline $\mathrm{Al}_{2} \mathrm{O}_{\mathrm{B}} \ldots \ldots$ & .0013 & 0.37 & $\mathrm{Al}_{2} \mathrm{O}_{3} \ldots \ldots \ldots \ldots$ & .0013 \\
\hline $\mathrm{SO}_{4} \ldots \ldots \ldots$ & .0477 & 13.12 & KOl ................ & .0157 \\
\hline Cl $\ldots \ldots \ldots \ldots$ & .0075 & 2.08 & $\mathrm{~K}_{2} \mathrm{CO}_{3} \ldots \ldots \ldots \ldots$ & .0046 \\
\hline $\mathrm{Ca} . . . \ldots \ldots$ & .0489 & 13.53 & $\mathrm{Na}_{2} \mathrm{CO}_{3} \ldots \ldots \ldots \ldots$ & .0550 \\
\hline $\mathbf{M g} \ldots \ldots \ldots \ldots$ & .0124 & 3.46 & $\mathrm{Na}_{2} \mathrm{SO}_{4} \ldots \ldots \ldots \ldots$ & .0705 \\
\hline Na........... & .0467 & 12.92 & $\mathrm{CaCO}_{3} \ldots \ldots \ldots \ldots$ & .1222 \\
\hline \multirow[t]{2}{*}{$\mathbf{K} \ldots \ldots \ldots \ldots$} & .0100 & 2.77 & $\mathrm{MgCO}_{3} \ldots \ldots \ldots \ldots$ & .0434 \\
\hline & .2071 & & & .3453 \\
\hline \multirow[t]{2}{*}{$\mathrm{CO}_{3} \ldots \ldots \ldots$} & .1544 & 42.72 & \multirow{2}{*}{\multicolumn{2}{|c|}{ 95. 52 per cent. accounted for. }} \\
\hline & .3615 & 100.00 & & \\
\hline
\end{tabular}

If the loss in the last column is due to the presence of alkaline bicarbonates, and reckoned in the latter form to make up 100 per cent., we have-

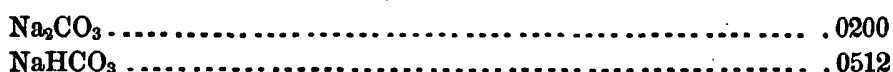


WASHINGTON LABORATORY.

[BULI. 9.

HOT SPRING, WARD'S RANCH, FOOT OF GRANITE MOUNTAIN, NEVADA.

Analysis by T. M. Chatard.

[Total solids: 1.1902 grammes to the liter.]

\begin{tabular}{|c|c|c|c|}
\hline \multicolumn{2}{|l|}{ Found. } & \multirow{2}{*}{$\frac{\begin{array}{c}\text { Per cent. } \\
\text { of total } \\
\text { solids. }\end{array}}{9.60}$} & Probable combination. \\
\hline $\mathrm{SiO}_{2} . . . . . . .$. & 0.1136 & & $\mathrm{SiO}_{2}$, free $\ldots . . . \ldots . . \quad 0.0180$ \\
\hline $\mathrm{SO}_{4} \ldots \ldots \ldots$. & 0.3901 & 32.97 & $\cdot \mathrm{Na}_{2} \mathrm{SiO}_{3} \ldots \ldots \ldots \ldots . . .0 .1942$ \\
\hline $\mathbf{C l} \ldots \ldots \ldots$ & 0.2396 & 20.25 & $\mathrm{Na}_{2} \mathrm{SO}_{4} \ldots \ldots \ldots \ldots . . .6 .4267$ \\
\hline $\mathrm{CO}_{3} \ldots \ldots \ldots$ & trace & $\ldots \ldots \ldots$ & $\mathrm{NaCl} \ldots \ldots \ldots \ldots \ldots . . . .3665$ \\
\hline Ca........... & 0.0367 & 3.10 & KC1............. 0.0363 \\
\hline $\mathbf{M g} \ldots \ldots \ldots$ & 0.0034 & 0.29 & $\mathrm{CaSO}_{4} \ldots \ldots \ldots \ldots \ldots . . \ldots .1247$ \\
\hline Na.......... & 0.3554 & 30.03 & $\mathrm{MgSO}_{4} \ldots \ldots \ldots \ldots \ldots 0.0 .0179$ \\
\hline $\begin{array}{l}\mathbf{K} \ldots \ldots \ldots \ldots \ldots \\
\mathbf{i} \mathbf{i} \ldots \ldots \ldots \ldots \ldots\end{array}$ & $\begin{array}{r}0.0101 \\
\text { trace }\end{array}$ & 1.61 & 1.1834 \\
\hline \multirow[t]{2}{*}{$\mathrm{O}$ for $\mathrm{SiO}_{3} . .}$. & 0.0255 & 2.15 & 99.43 per cent. accounted for. \\
\hline & 1. 1834 & 100.00 & . \\
\hline
\end{tabular}

hot spring, at hot spring station, nevada, C. P. R. R.

Analysis by T. M. Chatard.

[Total solids: 2.4924 grammes to the liter.]

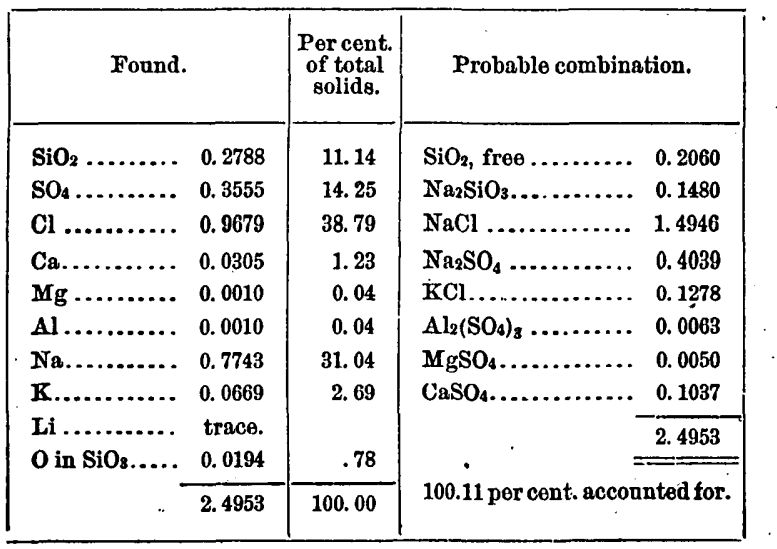


LARGER SODA LAKE, NEAR RAGTOWN, NEVADA.

Specific gravity of water, 1.101. Two analyses (Chatard) were made, one of a sample taken just below the surface, the other of water from a depth of 30.5 meters.

$$
\text { A.-Surface sample. }
$$

[Total solids : 125.1300 grammes to the liter.]

\begin{tabular}{|c|c|c|c|}
\hline \multicolumn{2}{|l|}{ Found. } & $\begin{array}{l}\text { Percent. } \\
\text { of total } \\
\text { solids. }\end{array}$ & Probable combination. \\
\hline $\mathrm{SiO}_{2} \ldots \ldots \ldots$ & 0.304 & 0.24 & $\mathrm{SiO}_{2} \ldots \ldots \ldots \ldots$ \\
\hline $\mathrm{SO}_{4} \ldots \ldots \ldots$ & 12.960 & 10.36 & $\mathbf{K C l} \ldots \ldots \ldots \ldots$ \\
\hline $\mathrm{Cl} \ldots \ldots \ldots$ & 45. 690 & 36.51 & $\mathrm{NaCl} . . . \ldots . . . . .$. \\
\hline $\mathrm{B}_{4} \mathrm{O}_{7} \ldots \ldots \ldots$ & 0.314 & 0.25 & $\mathrm{Na}_{2} \mathrm{SO}_{4} \ldots \ldots \ldots \ldots$ \\
\hline $\mathbf{M g} \ldots \ldots \ldots$ & 0.270 & 0.22 & $\mathrm{Na}_{2} \mathrm{CO}_{3} \ldots \ldots \ldots$ \\
\hline $\mathrm{Na} . . . . . . .$. & 45.840 & 36.63 & $\mathrm{Na}_{2} \mathrm{~B}_{4} \mathrm{O}_{7} \ldots \ldots \ldots$ \\
\hline \multirow[t]{2}{*}{$\mathbf{K} \ldots \ldots \ldots$} & 2.520 & 2.01 & $\mathrm{MgCO}_{3} \ldots \ldots \ldots \ldots$ \\
\hline & 107.898 & . & 123.518 \\
\hline \multirow[t]{2}{*}{$\mathrm{CO}_{3} \ldots \ldots \ldots$} & 17.232 & 13.78 & \multirow[t]{2}{*}{98.71 per cent. accounted for. } \\
\hline & 125.130 & 100.00 & \\
\hline
\end{tabular}

If the loss in the last column be reckoned as due to the presence of bicarbonates, it gives, to make up 100 per cent. :

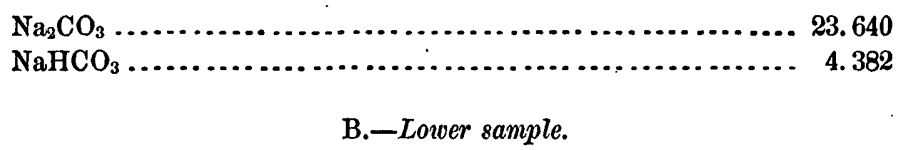

[Total solids : 125.1500 grammes to the liter.]

\begin{tabular}{|c|c|c|c|}
\hline \multicolumn{2}{|l|}{ Found. } & $\begin{array}{l}\text { Per cent. } \\
\text { of total } \\
\text { solids. }\end{array}$ & Probable combination. \\
\hline $\mathrm{SiO}_{2} \ldots \ldots \ldots$ & 0.310 & 0.25 & $\mathrm{SiO}_{2} \ldots \ldots \ldots \ldots$ \\
\hline $\mathrm{SO}_{4} \ldots \ldots . .$. & 13.150 & 10.50 & KCl ............. \\
\hline Cl $\ldots \ldots \ldots \ldots$ & 44. 270 & 35. 38 & 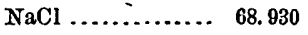 \\
\hline $\mathrm{B}_{4} \mathrm{O} ; \ldots$ & 0.327 & 0.26 & $\mathrm{Na}_{2} \mathrm{SO}_{4} \ldots \ldots \ldots \ldots \ldots .19 .450$ \\
\hline$M g \ldots \ldots . . . .$. & 0.270 & 0.21 & $\mathrm{Na}_{2} \mathrm{CO}_{3} \ldots \ldots \ldots \ldots \ldots$ \\
\hline $\mathbf{N a} \ldots \ldots \ldots$ & 44. 270 & 35.38 & $\mathrm{Na}_{2} \mathrm{~B}_{4} \mathrm{O}_{7} \ldots \ldots \ldots \ldots . \quad 0.417$ \\
\hline \multirow[t]{2}{*}{ K........... } & 2.670 & \multirow[t]{2}{*}{2.13} & $\mathrm{MgCO}_{3} \ldots \ldots \ldots \ldots$ \\
\hline & 105.267 & & 119.997 \\
\hline \multirow[t]{2}{*}{$\mathrm{CO}_{3} \ldots \ldots \ldots$} & 19.883 & 15.89 & 95.88 per cent. accounted for. \\
\hline & 125.150 & 100.00 & . \\
\hline
\end{tabular}

Reckoning the loss in the last column as in the case of the surface sample, we have-

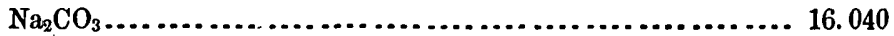

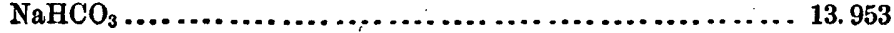


From the waters of this lake sodium carbonate is manufactured upon a commercial scale. Several brines and products obtained in this - manufacture were qualitatively examined by Dr. Chatard. A more complete investigation may be undertaken at some future time. A pale pink-colored brine, from which summer soda had been taken, and in which salt had begun to crystallize, was found to contain carbonates, chlorides, and sulphates of soaium and potassium, with some alkaline phosphates and borates. The pink color was probably due to organic matter. A concentrated brine from the Little Soda Lake contained similar ingredients, minus the phosphates. In a crystalline mass from a vat at the same locality the same constituents were found, with phosphates and a trace of lime. From this vat five annual crops of soda were said to have been taken. The sodium carbonate as it goes to market from the smaller Soda Lake, contains as impurities, sand, clay, considerable chloride, some sulphate, a little borate, a trace of phosphate, and some potassium salts.

\section{MONO LAKE, OALIFORNIA.7}

A sample of water taken near the surface. Analysis by T. M. Chatard. Specific gravity, 1.045 at $15^{\circ} .5$.

[Total solids : 51.8500 grammes to the liter.]?

\begin{tabular}{|c|c|c|}
\hline Found. & $\begin{array}{l}\text { Per cent. } \\
\text { of total } \\
\text { solids. }\end{array}$ & Probable combination. \\
\hline $\mathrm{SiO}_{2} \ldots \ldots \ldots . . .0 .2800$ & 0.54 & 'Sio ................ 0.2800 \\
\hline $\begin{array}{llll}\mathrm{SO}_{4} & \ldots \ldots \ldots . & 6.8100\end{array}$ & 13.11 & $\mathrm{KCl} \ldots \ldots \ldots \ldots \ldots .2 .2300$ \\
\hline $\mathrm{Cl} \ldots \ldots \ldots \ldots 12.1300$ & 23. 39 & $\mathrm{NaCl} \ldots \ldots \ldots \ldots \ldots . . . .18 .2200$ \\
\hline $\mathrm{B}_{4} \mathrm{O}_{7} \ldots \ldots \ldots 0.1600$ & 0.34 & $\mathrm{Na}_{2} \mathrm{SO}_{4} \ldots \ldots \ldots \ldots . . \ldots 10.0700$ \\
\hline$C \mathrm{Ca} \ldots \ldots \ldots \ldots, 0.2800$ & 0.55 & $\mathrm{Na}_{2} \mathrm{~B}_{4} \mathrm{O}_{7} \ldots \ldots \ldots . .0 .2000$ \\
\hline 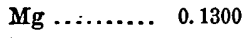 & 9.28 & $\mathrm{Na}_{2} \mathrm{CO}_{3} \ldots \ldots \ldots \ldots \ldots . . .19 .4900$ \\
\hline Na......... 18.9100 & 36.46 & $\mathrm{Ca}_{2} \mathrm{CO}_{3} \ldots \ldots \ldots \ldots . .6 .6800$ \\
\hline \multirow[t]{2}{*}{$\mathbf{K} \ldots \ldots \ldots \ldots$} & 2.23 & $\mathrm{MgCO}_{3} \ldots \ldots \ldots \ldots . . . \quad 0.3600$ \\
\hline & & 51.5300 \\
\hline \multirow[t]{2}{*}{$\mathrm{CO}_{3} \ldots \ldots \ldots 11.9800$} & 23.10 & 99.60 per cent. accounted for. \\
\hline & 100.00 & \\
\hline
\end{tabular}

Mud from the bottom of the lake, taken at a depth of over 30 meters, was also examined qualitatively. The portion soluble in water contained chlorides of potassium and sodium, no sulphates, some carbonates, and traces of sulphides. The portion soluble in hydrochloric acid contained iron, alumina, lime, and alkalies, with a little boric acid. The insoluble residue consisted of sand and silica.

${ }^{7}$ A second sample of Mono Lake water, taken from a depth of 30 meters, contained 52.8560 grammes to the liter. 
SPRING ON TUFA CRAG, IN MONO LAKE.

Analysis by T. M. Chatard.

[Total solids: 0.2918 gramme to the liter.]

\begin{tabular}{|c|c|c|}
\hline Found. & $\begin{array}{l}\text { Per cent. } \\
\text { of total } \\
\text { solids. }\end{array}$ & Probable combination. \\
\hline $\mathrm{SiO}_{2} \ldots \ldots \ldots \ldots 0178$ & 6. 10 & $\mathrm{SiO}_{2} \ldots \ldots \ldots \ldots \ldots \ldots . .0178$ \\
\hline $\mathrm{SO}_{4} \ldots \ldots \ldots \ldots .0546$ & 18. 71 & $\mathrm{KCl} \ldots \ldots \ldots \ldots \ldots . . . .0169$ \\
\hline Cl ............0144 & 4. 93 & $\mathrm{NaCl} \ldots \ldots \ldots \ldots \ldots . . . . . .0104$ \\
\hline Ca.............0414 & 14.19 & $\mathrm{Na}_{2} \mathrm{SO}_{4} \ldots \ldots \ldots \ldots \ldots \ldots .0799$ \\
\hline $\mathrm{Mg} \ldots \ldots \ldots \ldots .0044$ & 1.51 & $\mathrm{Na}_{2} \mathrm{CO}_{3} \ldots \ldots \ldots \ldots \ldots . . \ldots 506^{\circ}$ \\
\hline $\mathrm{Na} \ldots \ldots \ldots \ldots . . . .0513$ & 17.58 & $\mathrm{CaCO}_{3} \ldots \ldots \ldots \ldots \ldots \ldots+1035$ \\
\hline K............0088 & 3. 02 & $\mathrm{MgCO}_{3} \ldots \ldots \ldots \ldots \ldots \ldots \ldots$ \\
\hline .1927 & & .2945 \\
\hline $\mathrm{CO}_{3} \ldots \ldots \ldots \ldots .0991$ & 33.96 & Total, 100.91 per cent. \\
\hline .2918 & 100.00 & \\
\hline
\end{tabular}

The water of the "Petroleum Spring," on an island in Mono Lake, yielded a solid residue of 0.8775 gramme to the liter. It contains carbonates, chlorides, and silicates; the bases being sodium, potassium, calcium, magnesium, and aluminum.

WARM SPRING, AT WARM SPRING STATION, MONO BASIN.

Analysis by T. M. Chatard.

[Total solids : 2.0850 grammes to the liter.]

\begin{tabular}{|c|c|c|}
\hline Found. & $\begin{array}{l}\text { Per cent. } \\
\text { of total } \\
\text { solids. }\end{array}$ & Probable combination. \\
\hline $\mathrm{SiO}_{3} \ldots \ldots \ldots \ldots . .1545$ & 7.46 & $\mathrm{Al}_{2} \mathrm{O}_{3} \ldots \ldots \ldots \ldots, 0.0018$ \\
\hline $\mathrm{SO}_{4} \ldots \ldots \ldots \ldots: 0.3131$ & 15. 13 & KCl ............. 0.1203 \\
\hline $\mathrm{Cl} \ldots \ldots \ldots \ldots \ldots .2272$ & -10.98 & $\mathrm{NaCl} \ldots \ldots \ldots \ldots \ldots . . .2799$ \\
\hline $\mathrm{Ca} \ldots \ldots \ldots \ldots .0 .0589$ & 2.84 & $\mathrm{Na}_{2} \mathrm{SO}_{4} \ldots \ldots \ldots \ldots . \quad 0.4631$ \\
\hline $\mathbf{M g} \ldots \ldots \ldots \ldots 0.0604$ & 2.92 & $\mathrm{Na}_{2} \mathrm{SiO}_{3} \ldots \ldots \ldots \ldots . . .2480$ \\
\hline Na.......... 0.6116 & 29.56 & $\mathrm{Na}_{2} \mathrm{CO}_{3} \ldots \ldots \ldots \ldots . \quad 0.5972$ \\
\hline K.......... 0.0630 & 3. 05 & $\mathrm{CaCO}_{3} \ldots \ldots \ldots \ldots \ldots . . .6 .1475$ \\
\hline Li .......... trace. & ............. & $\mathrm{MgCO}_{3} \ldots \ldots \ldots \ldots \ldots .2114$ \\
\hline $\mathrm{Al}_{2} \mathrm{O}_{3} \ldots \ldots \ldots \ldots .0018$ & 0.09 & 2. 0692 \\
\hline 1.4905 & & 99.24 per cent. acconnted for. \\
\hline $\mathrm{CO}_{3} \ldots \ldots \ldots \ldots . . \ldots 0.5945$ & 27.97 & \\
\hline 2.0850 & 100.00 & . \\
\hline
\end{tabular}


BOILING SPRING, FOUR MILES S. E. OF SHAFFER'S RANOH, HONEY LAKE VALLEY, CALIFORNIA. Analysis by T. M. Chatard.

[Total solids : 1,0218 gramme to the liter.]

\begin{tabular}{|c|c|c|c|}
\hline \multicolumn{2}{|l|}{ Found. } & \multirow{2}{*}{$\begin{array}{c}\begin{array}{c}\text { Per cent. } \\
\text { of total } \\
\text { solids. }\end{array} \\
12.83\end{array}$} & Probable combination. \\
\hline $\mathrm{SiO}_{2} \ldots \ldots \ldots$ & 0.1310 & & $\mathrm{SiO}_{2}$, free $\ldots . . . \ldots . .0 .1008$ \\
\hline $\mathrm{SO}_{4} \ldots \ldots \ldots \ldots$ & $0.349 \dot{2}$ & 34.19 & $\mathrm{Na}_{2} \mathrm{SiO}_{3} \ldots \ldots \ldots \ldots .0 .0613$ \\
\hline $\mathrm{Cl} \ldots \ldots \ldots$ & 0.2070 & 20.27 & $\mathrm{Na}_{2} \mathrm{SO}_{4} \ldots \ldots \ldots \ldots . . \quad 0.4715$ \\
\hline $\mathrm{Ca} \ldots . . . \ldots . .$. & 0.0121 & 1.18 & $\mathrm{NaCl} \ldots \ldots \ldots \ldots \ldots . . . .3266$ \\
\hline $\mathbf{M g} \ldots \ldots \ldots$ & 0.0004 & 0.04 & KCl............. 0.0180 \\
\hline Na........... & 0.3040 & 29.78 & $\mathrm{CaSO}_{4} \ldots \ldots \ldots \ldots \ldots . . .0 .0409$ \\
\hline $\mathbf{K} \ldots \ldots \ldots \ldots$ & 0.0094 & 0.92 & $\mathrm{MgSO}_{4} \ldots \ldots \ldots \ldots .0 .0020$ \\
\hline \multirow[t]{2}{*}{ O for $\mathrm{SiO}_{3} \ldots$} & 0.0080 & 0.79 & 1.0211 \\
\hline & 1.0211 & 100.00 & 99. 93 per cont. accounted for. \\
\hline
\end{tabular}

Two other springs in Honey Lake Valley were examined qualitatively. In the water of the High Rock Spring were found carbonates, chlorides, and sulphates of calcium, magnesium, sodium and potassium, with a little silica. The Lower Hot Spring contained chlorides and sulphates of the same bases.

\section{LAKE TAHOE, OALIFORNIA.}

Analysis by F. W. Clarke.

[Total solids : 0.0730 grammo to the liter.]

\begin{tabular}{|c|c|c|c|}
\hline \multicolumn{2}{|l|}{ Found. } & \multirow{2}{*}{$\begin{array}{c}\begin{array}{c}\text { Per cent. } \\
\text { of total } \\
\text { solids. }\end{array} \\
18.77\end{array}$} & $\begin{array}{l}\text { Probable combination, } \\
\end{array}$ \\
\hline $\mathrm{SiO}_{2} \ldots \ldots \ldots$ & .0137 & & $\mathrm{SiO}_{2} \ldots \ldots \ldots \ldots \ldots$ \\
\hline $\mathrm{SO}_{4} \ldots \ldots \ldots \ldots$ & .0054 & 7.40 & KCl ............... \\
\hline Cl $\ldots \ldots \ldots$ & .0023 & 3.14 & $\mathrm{NaCl} . . . \ldots \ldots \ldots . . .$. \\
\hline $\mathrm{Ca} \ldots \ldots \ldots$ & .0093 & 12.74 & $\mathrm{~K}_{2} \mathrm{SO}_{4} \ldots \ldots \ldots \ldots$ \\
\hline $\mathbf{M g} \ldots \ldots \ldots .$. & .0030 & 4.11 & $\mathrm{Na}_{2} \mathrm{SO}_{2} \ldots \ldots \ldots \ldots$ \\
\hline $\mathrm{Na} . . . . . . . .$. & .0073 & 10.00 & $\mathrm{Na}_{2} \mathrm{CO}_{3} \ldots \ldots \ldots \ldots . \quad .0117$ \\
\hline \multirow[t]{2}{*}{$\mathbf{K} \ldots \ldots \ldots$} & .0033 & 4.52 & $\mathrm{CaCO}_{3} \ldots \ldots \ldots \ldots \ldots . \quad .0233$ \\
\hline & .0443 & & $\mathrm{MgCO}_{3} \ldots \ldots, \ldots \ldots, \quad .0105$ \\
\hline \multirow[t]{2}{*}{$\mathrm{CO}_{3} \ldots \ldots \ldots . . .}$. & .0287 & 39.32 & .0723 \\
\hline & .0730 & 100.00 & 09.04 per cent. accounted for. \\
\hline
\end{tabular}

\section{ABERT LAKE, OREGON.}

The water of this lake was collected by I. C. Russell, at a point about 150 meters off from the west shore. It was analyzed by Mr. F. W. Taylor, of the Smithsonian Institution, and the analysis is here included 
merely for the purpose of completing the series of waters specially examined for the division of the Great Basin. Specific gravity, 1.02317.

Contents in one liter.

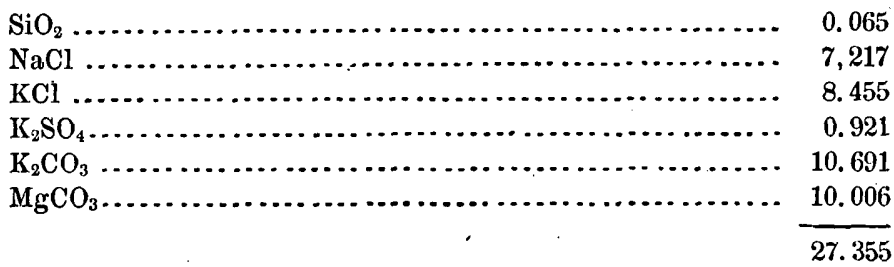

An efflorescence from the north shore of the lake, examined qualita. tively by T. M. Chatard, contained carbonates and chlorides of sodium and potassium, with traces of sulphates, phosphates, and calcium.

UTAH LAKE, UTAH.

Analysis by F. W. Clarke.

[Total solids: 6.3060 gramme to the liter.]

\begin{tabular}{|c|c|c|c|c|}
\hline \multicolumn{2}{|l|}{ Found. } & \multirow{2}{*}{$\begin{array}{c}\begin{array}{c}\text { Per cent. } \\
\text { of total } \\
\text { solids. }\end{array} \\
\text { 3. } 27\end{array}$} & \multicolumn{2}{|c|}{ Probable combination. } \\
\hline $\mathrm{SiO}_{2} \ldots \ldots \ldots$ & .0100 & & $\mathrm{SiO}_{2} \ldots$ & .0100 \\
\hline $\mathrm{SO}_{4} \ldots \ldots \ldots$ & .1306 & 42.68 & $\mathrm{NaCl}, \ldots . . . . . . . .$. & .0204 \\
\hline Cl $\ldots \ldots \ldots$ & .0124 & 4.04 & $\mathrm{Na}_{2} \mathrm{CO}_{3} \ldots \ldots \ldots \ldots$ & .0204 \\
\hline $\mathrm{Ca} \ldots \ldots \ldots \ldots$ & .0558 & 18.24 & $\mathrm{CaSO}_{4} \ldots . . . \ldots \ldots \ldots$ & .1849 \\
\hline $\mathrm{Mg} \ldots \ldots \ldots$ & .0186 & 6. 08 & $\mathrm{CaCO}_{3} \ldots \ldots \ldots \ldots$ & .0038 \\
\hline \multirow[t]{2}{*}{$\mathrm{Na} . . . . . . . .}$. & .0178 & 5.81 & $\mathrm{MgCO}_{3} \ldots \ldots \ldots \ldots$ & .0644 \\
\hline & .2452 & & & .3039 \\
\hline \multirow[t]{2}{*}{$\mathrm{CO}_{3} \ldots \ldots \ldots$} & .0608 & 19.88 & \multirow{2}{*}{\multicolumn{2}{|c|}{99.31 per cent accounted for. }} \\
\hline & .3060 & 100.00 & & \\
\hline
\end{tabular}

A little potassium is present, but was not separately estimated. GITY CREEK, UTAH.

Water collected above the reservoir which supplies Salt Lake City. Analysis by T. M. Chatard.

[Total solids : 0.2400 gramme to the liter.]

\begin{tabular}{|c|c|c|c|c|}
\hline Found. & - & $\begin{array}{l}\text { Per cent. } \\
\text { of total }\end{array}$ & \multicolumn{2}{|c|}{ Probable combination, } \\
\hline $\mathrm{SiO}_{2} \ldots, \ldots, \ldots$ & .0090 & 3.69 & $\mathrm{SiO}_{2} \ldots \ldots \ldots \ldots \ldots$ & .0090 \\
\hline $\mathrm{Al}_{2} \mathrm{O}_{3} \ldots \ldots \ldots$ & .0010 & 0.41 & $\mathrm{Al}_{2} \mathrm{O}_{3} \ldots \ldots \ldots \ldots \ldots$ & .0010 \\
\hline $\mathrm{SO}_{4} \ldots \ldots \ldots \ldots$. & .0070 & 2.87 & $\mathrm{NaCl} . . . . . . . . . . . .$. & .0216 \\
\hline $\mathrm{Cl} \ldots \ldots \ldots \ldots$ & .0131 & 5.38 & $\mathrm{Na}_{2} \mathrm{CO}_{3} \ldots \ldots \ldots$ & .0014 \\
\hline $\mathrm{Ca} \ldots \ldots \ldots$ & .0589 & 24.19 & $\mathrm{CaSO}_{4} \ldots \ldots \ldots \ldots$ & .0090 \\
\hline $\mathrm{M}_{\mathrm{r}} \ldots \ldots \ldots .$. & .0174 & 7.15 & $\mathrm{CaCO}_{3} \ldots \ldots \ldots$ & .1400 \\
\hline \multirow[t]{2}{*}{$\mathrm{Na} . . . . . . .}$. & .0091 & 3.74 & $\mathrm{stgCO}_{3} \ldots \ldots \ldots \ldots$ & .0606 \\
\hline & .1155 & & & .2435 \\
\hline \multirow[t]{2}{*}{$\mathrm{CO}_{3} \ldots \ldots \ldots$} & .1215 & 52.57 & \multirow{2}{*}{\multicolumn{2}{|c|}{ Total, 101.45 per cent. }} \\
\hline & .2400 & 100.00 & & \\
\hline
\end{tabular}


BEAR RIVER, UTAH.

Analysis by F. W. Clarke.

[Total solids : 0.1845 gramme to the liter.]

\begin{tabular}{|c|c|c|c|}
\hline \multicolumn{2}{|l|}{ Found. } & \multirow{2}{*}{$\begin{array}{c}\begin{array}{c}\text { Per cent. } \\
\text { of total } \\
\text { solids. }\end{array} \\
3.79\end{array}$} & Probable combination. \\
\hline $\mathrm{SiO}_{2} \ldots \ldots . .$. & .0070 & & $\mathrm{SiO}_{2} \ldots \ldots \ldots \ldots \ldots . \quad .0070$ \\
\hline $\mathrm{SO}_{4} \ldots \ldots \ldots$. & .0105 & 5.69 & $\mathrm{NaCl}, \ldots . . . \ldots \ldots . .$. \\
\hline Cl $\ldots \ldots \ldots \ldots$ & 0049 & 2.65 & $\mathrm{Na}_{2} \mathrm{SO}_{4} \ldots \ldots \ldots \ldots$ \\
\hline $\mathrm{Ca} \ldots \ldots \ldots$ & .0432 & 23.41 & $\mathrm{CaCO}_{3} \ldots \ldots \ldots \ldots$ \\
\hline $\mathbf{M g} \ldots \ldots \ldots .$. & .0125 & 6. 78 & $\mathrm{MgCO}_{3} \ldots \ldots \ldots \ldots . . . . .0438$ \\
\hline Na........... & .0082 & 4.44 & .1824 \\
\hline & .0863 & & 98. 86 per cent accounted for. \\
\hline $\mathrm{CO}_{3} \ldots \ldots \ldots$ & .0982 & 53.24 & - \\
\hline & .1845 & 100.00 & \\
\hline
\end{tabular}

UTAII HOT SPRINGS, EIGHT MILES N. OF OGDEN, UTAH.

Water received throngh the Smithsonian Institution. Reported temperature $55^{\circ}$. Analysis by F. W. Clarke.

[Total solids: 23.1150 grammes to the liter.]

\begin{tabular}{|c|c|c|}
\hline Found. & $\begin{array}{l}\text { Per cent. } \\
\text { of total } \\
\text { solids. }\end{array}$ & Probable combination. \\
\hline $\mathrm{SiO}_{2} \ldots \ldots \ldots \ldots, 0.0460$ & 0.20 & $\mathrm{SiO}_{2} \ldots \ldots \ldots \ldots \ldots \ldots, 0.0460$ \\
\hline $\mathrm{Al}_{2} \mathrm{O}_{3} \ldots \ldots \ldots, 0.0040$ & 0.02 & $\mathrm{Al}_{2} \mathrm{O}_{3} \ldots \ldots \ldots \ldots, 0.0040$ \\
\hline SOA............ & 0.94 & $\mathrm{KCl} 1 \ldots \ldots \ldots \ldots \ldots, \mathbf{1 . 6 7 3 2}$ \\
\hline C1 $\ldots \ldots \ldots \ldots 13.7030$ & 59.28 & $\mathrm{NaCl} \ldots \ldots \ldots \ldots \ldots 18.0168$ \\
\hline Br.......... trace. & $\ldots \ldots \ldots$ & $\mathrm{CaCl}_{2} \ldots \ldots \ldots \ldots \ldots \quad 2.9187$ \\
\hline $\mathrm{CO}_{3} \ldots \ldots \ldots$ undet. & ............ & $\mathrm{MgCl}_{2} \ldots \ldots \ldots \ldots \ldots . \ldots .1398$ \\
\hline $\mathrm{Ca} \ldots \ldots \ldots \ldots, 1.1428$ & 4.83 & $\mathrm{CaSO}_{4} \ldots \ldots \ldots \ldots \ldots \ldots . \quad 0.3094$ \\
\hline $\mathrm{Mg} \ldots \ldots \ldots \ldots .0 .0929$ & 0.40 & $\mathrm{MgCO}_{3} \ldots \ldots \ldots \ldots . .20 .2016$ \\
\hline Na......... 7.0825 & 30.64 & \multirow{4}{*}{$\begin{array}{l}\text { Total, } 100.84 \text { per cent. } \\
\end{array}$} \\
\hline K.......... 0.8759 & 3.79 & \\
\hline Li ............ trace. & & \\
\hline 23. 1655 & 100.10 & \\
\hline
\end{tabular}

The $\mathrm{CO}_{3}$ in the last column, having been proved to be present, was computed to satisfy the excess of magnesium after the other acids had all been balanced. The water as received contained no iron in solution, but held an abundant ferruginous deposit. 


\section{HV́INGSTON WARM SPRINGS, MONTANẠ.}

Water received from A. C. Peale. Analysis by F. W. Clarke. Free $\mathrm{H}_{2} \mathrm{~S}$ present.

[Total solids: 0.7575 gramme to the liter.]

\begin{tabular}{|c|c|c|c|c|}
\hline \multicolumn{2}{|c|}{ Found. } & \multirow{2}{*}{$\frac{\begin{array}{c}\text { Per cent. } \\
\text { of total } \\
\text { solids. }\end{array}}{3.83}$} & \multicolumn{2}{|c|}{ Probable combination. } \\
\hline $\mathrm{SiO}_{2} \ldots \ldots \ldots$ & .0290 & & $\mathrm{SiO}_{2} \ldots \ldots \ldots \ldots \ldots$ & .0290 \\
\hline $\mathrm{SO}_{4} \ldots \ldots \ldots$ & .2224 & 29.37 & $\mathrm{KCl} \ldots \ldots \ldots \ldots \ldots$ & .0078 \\
\hline $\mathrm{Cl} \ldots \ldots \ldots$ & .0124 & 1.64 & $\mathrm{NaCl} . . . . . . . . . . .$. & .0143 \\
\hline $\mathrm{Ca} \ldots \ldots \ldots$ & .1678 & 22.11 & $\mathrm{Na}_{2} \mathrm{CO}_{3} \ldots \ldots \ldots \ldots$ & .0461 \\
\hline $\mathbf{M g} \ldots . . . .$. & .0438 & 5.79 & $\mathrm{CaCO}_{3} \ldots \ldots \ldots \ldots$ & .1880 \\
\hline $\mathrm{Na} \ldots . . . .$. & .0256 & 3. 38 & $\mathrm{CaSO}_{4} \ldots \ldots \ldots \ldots$ & $.31 \dot{50}$ \\
\hline \multirow[t]{2}{*}{ К........... } & .0041 & 0.55 & $\mathrm{MgCO}_{3} \ldots \ldots \ldots \ldots$ & .1533 \\
\hline & .5051 & & & .7535 \\
\hline \multirow[t]{2}{*}{$\mathrm{CO}_{3} \ldots \ldots \ldots$} & .2524 & 33.33 & \multirow{2}{*}{\multicolumn{2}{|c|}{99.47 per cent. accounted for. }} \\
\hline & .7575 & 100.00 & & \\
\hline
\end{tabular}

WARM SPRINGS OF EMIGRANT GULH, YELLOWSTONE VALLEY, MONTANA.

Water received from A. C. Peale. Analysis by F. W. Clarke.

['Total solids : 0.2350 gramme to the liter.]

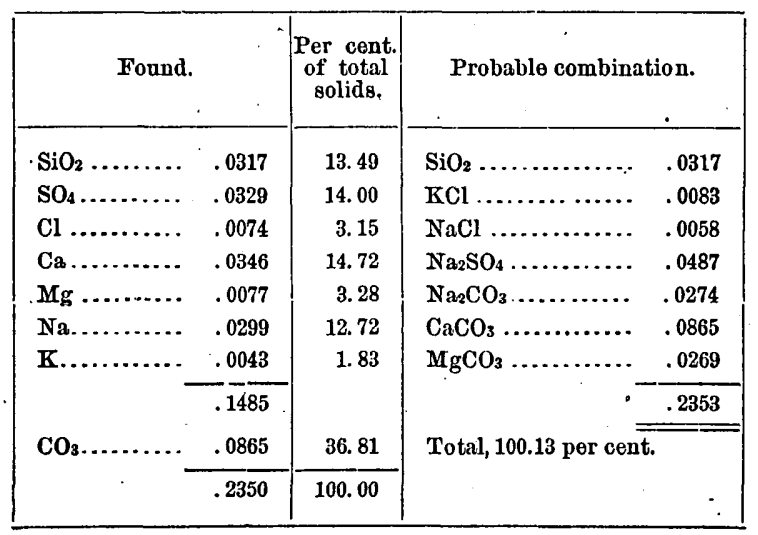


HBLENA HOT SPRINGS, HELENA, MONT.

Water received from A. C. Peale. Reported temperature, 60.5०. Analysis by F. W. Clarke.

[Total solids : 0.6225 gramme to the liter.]

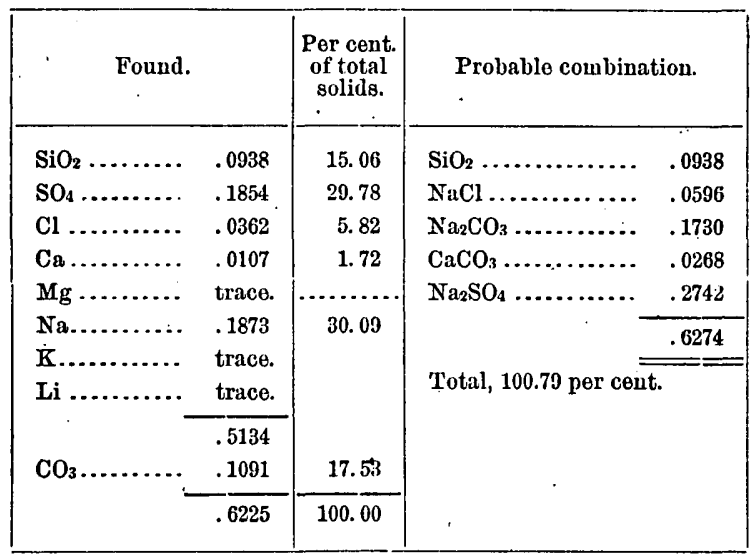

MILL CREEK COLD SPIRING, YELLOWSTONE VALLEY, MONTANA.

Water received from A. C. Peale. Highly effervescent. Reported temperature, $4.5^{\circ}$. Analysis by F. W. Clarke.

[Total solids: 3.8125 grammos to the liter.]

\begin{tabular}{|c|c|c|c|}
\hline \multicolumn{2}{|l|}{ Found. } & $\begin{array}{l}\text { Per cent. } \\
\text { of total } \\
\text { solids. }\end{array}$ & Probable combination. \\
\hline $\mathrm{SiO}_{2} \ldots \ldots \ldots$ & 0.0250 & 0.66 & $\mathrm{SiO}_{2} \ldots \ldots \ldots \ldots \ldots, 0.0250$ \\
\hline $\mathrm{Al}_{2} \mathrm{O}_{3} . \mathrm{Fe}_{2} \mathrm{O}_{3}$ & 0.0875 & 2.29 & $\mathrm{KCl} \ldots \ldots \ldots \ldots \ldots, 0.098 \mathrm{i}$ \\
\hline $\mathrm{SO}_{4} \ldots . . . \ldots$ & 0.6500 & 17.115 & $\mathrm{NaCl} \ldots \ldots \ldots \ldots \ldots . . . .3795$ \\
\hline $\mathrm{Cl} \ldots \ldots \ldots$ & 0.2771 & 7.27 & $\mathrm{Na}_{2} \mathrm{SO}_{4} \ldots \ldots \ldots \ldots . \quad 0.9402$ \\
\hline$I \ldots \ldots \ldots \ldots$ & trace. & ........ & $\mathrm{Na}_{2} \mathrm{CO}_{3} \ldots \ldots \ldots \ldots . .0 .9853$ \\
\hline $\mathrm{Ca} \ldots \ldots \ldots .$. & 0.3768 & 9.88 & $\mathrm{MgCO}_{3} \ldots \ldots \ldots \ldots \quad 0.2838$ \\
\hline $\mathbf{M g} \ldots . . . .$. & 0.0811 & 2.13 & $\mathrm{FeCO}_{3} \ldots \ldots \ldots \ldots, 0.1268$ \\
\hline $\mathrm{Na} .$. & 0.8814 & 23.12 & $\mathrm{CaCO}_{3} \ldots \ldots \ldots \ldots . . .6 .9270$ \\
\hline $\mathbf{K} \ldots \ldots \ldots$ & 0.0513 & 1. 34 & $\mathrm{CaSO}_{4} \ldots \ldots \ldots \ldots \ldots . \quad 0.0204$ \\
\hline \multirow[t]{2}{*}{$\mathbf{L i} \ldots \ldots \ldots \ldots$} & trace. & & \multirow{4}{*}{99.31 per cont. accounted for. } \\
\hline & 2.4302 & & \\
\hline \multirow[t]{2}{*}{$\mathrm{CO}_{3} \ldots \ldots \ldots$} & 1. 3823 & 36.26 & \\
\hline & 3. 8125 & 100.00 & \\
\hline
\end{tabular}

In this analysis the amount of available material was insufficient. The iron in the third column is made to include the trifling quantity of . aluminum which, though present, could not be separately estimated; and the calcium sulphate was directly determined as such in the insoluble residue left upon evaporating the water to dryness. The carbonates in the original water are all undoubtedly bicarbonates, and, reckoned as such, should receive the following weights: Sodium bicarbonate, 1.5618; calcium bicarbonate, 1.5017 ; magnesium bicarbonate, .4932 ; ferrous bicarbonate, $\mathbf{. 1 9 4 5}$. 
VIRGINIA HOT SPRINGS, BATH COUNTY, VIRGINIA.

The waters of six different springs were received from the Virginia Hot Springs Company, as follows :

A. Boiler bath. Temperature, $41^{\circ} \mathrm{C}$.

B. Hot spout bath. Temperature, $40^{\circ} .5 \mathrm{C}$.

C. Octagon bath. Temperature, $38^{\circ} \mathrm{C}$.

D. New hot spring. Temperature, $37 \circ \mathrm{C}$.

E. "Sulphur" bath. Temperature, $36 \circ .5 \mathrm{C}$.

F. "Magnesian" spring. Temperature, $25 \circ .5 \mathrm{C}$.

Analyses by F. W. Clarke. Traces of bromine were found in $\mathbf{A}$ and B. The other waters were so similar to these that bromine was not specially sought for in them.

\section{A.-Boiler bath.}

[Total solids : 0.5975 gramme to the liter.]

\begin{tabular}{|c|c|c|c|c|}
\hline \multicolumn{2}{|l|}{ Found. } & \multirow{2}{*}{$\begin{array}{c}\begin{array}{c}\text { Per cent. } \\
\text { of total } \\
\text { solids. }\end{array} \\
4.60\end{array}$} & \multicolumn{2}{|c|}{ Probable combination. } \\
\hline $\mathrm{SiO}_{2} \ldots \ldots . .$. & .0275 & & $\mathrm{SiO}_{2} \ldots \ldots \ldots \ldots \ldots$ & .0275 \\
\hline SOA......... & .1319 & 22.07 & $\mathrm{Al}_{2} \mathrm{O}_{3} \ldots \ldots \ldots \ldots$ & .0020 \\
\hline $\mathrm{Cl} \ldots \ldots \ldots$ & .0050 & 0.83 & $\mathrm{KCl} \ldots \ldots \ldots \ldots$ & .0105 \\
\hline $\mathrm{Al}_{2} \mathrm{O}_{3} \ldots \ldots \ldots$ & .0020 & $\cdot 0.32$ & $\mathrm{~K}_{2} \mathrm{SO}_{4} \ldots \ldots \ldots \ldots$ & .0138 \\
\hline Ca........... & .1356 & 22.69 & $\mathrm{Na}_{2} \mathrm{SO}_{4} \ldots \ldots \ldots \ldots$ & .0370 \\
\hline $\mathbf{M g}, \ldots \ldots \ldots$ & .0357 & 5.96 & $\mathrm{CaSO}_{4} \ldots . . . \ldots \ldots$ & .1407 \\
\hline $\mathrm{Na} . . . \ldots . . .$. & .0120 & 2.08 & $\mathrm{CaCO}_{3} \ldots \ldots \ldots \ldots$ & .2355 \\
\hline \multirow[t]{2}{*}{$\mathbf{K} \ldots \ldots \ldots \ldots$} & .0117 & 1.95 & $\mathrm{MgCO}_{3} \ldots \ldots \ldots$ & .1249 \\
\hline & .3614 & & & .5919 \\
\hline \multirow[t]{2}{*}{$\mathrm{CO}_{3} \ldots \ldots \ldots$} & .2361 & 39.50 & \multirow{2}{*}{\multicolumn{2}{|c|}{ 99. 06 per cent. accounted for. }} \\
\hline & .5975 & 100.00 & & \\
\hline
\end{tabular}

$$
\text { B.-Hot spout bath. }
$$

[Total solids : 0.5925 gramme to the liter.]

\begin{tabular}{|c|c|c|c|}
\hline \multicolumn{2}{|l|}{ Found. } & \multirow{2}{*}{$\begin{array}{c}\begin{array}{c}\text { Per cent. } \\
\text { of total } \\
\text { solids. }\end{array} \\
3.97\end{array}$} & Probable combination. \\
\hline $\mathrm{SiO}_{2} \ldots \ldots \ldots$. & .0235 & & $\mathrm{SiO}_{2} \ldots \ldots \ldots \ldots \ldots$ \\
\hline $\mathrm{SO}_{4} \ldots \ldots \ldots \ldots$ & .1298 & 21.91 & $\mathrm{Al}_{2} \mathrm{O}_{3} \ldots \ldots \ldots \ldots$ \\
\hline $\mathrm{Cl} \ldots \ldots \ldots$ & .0044 & 0.74 & KCl................. \\
\hline $\mathrm{Al}_{2} \mathrm{O}_{3} \ldots \ldots \ldots$ & .0025 & 0.42 & $\mathrm{~K}_{2} \mathrm{SO}_{4} \ldots \ldots \ldots \ldots$ \\
\hline $\mathrm{Ca} \ldots \ldots \ldots .$. & .1375 & 23. 21 & $\mathrm{Na}_{2} \mathrm{SO}_{4} \ldots \ldots \ldots \ldots$ \\
\hline $\mathbf{M g} \ldots \ldots \ldots$ & .0343 & 5. 79 & $\mathrm{CaSO}_{4} \ldots \ldots \ldots \ldots$ \\
\hline Na........... & .0091 & 1.53 & $\mathrm{CaCO}_{3} \ldots \ldots . . . \ldots$ \\
\hline \multirow[t]{2}{*}{ K........... } & .0132 & 2. 23 & $\mathrm{MgCO}_{3} \ldots \ldots \ldots$ \\
\hline & .3543 & & .5835 \\
\hline \multirow[t]{2}{*}{$\mathrm{COs} \ldots . . . . .}$. & .2382 & 40.20 & 98.46 per cent. accounted for \\
\hline & .5925 & 100.00 & • \\
\hline
\end{tabular}

Bull. 9 
C.-Octagon bath.

[Total solids : 0.5940 gramme to the liter.]

\begin{tabular}{|c|c|c|c|c|}
\hline \multicolumn{2}{|l|}{ Found. } & \multirow{2}{*}{$\begin{array}{c}\begin{array}{c}\text { Per cent. } \\
\text { of total } \\
\text { solids. }\end{array} \\
4.29\end{array}$} & \multicolumn{2}{|c|}{ Probable combination. } \\
\hline $\mathrm{SiO}_{2} \ldots \ldots \ldots$ & .0255 & & $\mathrm{SiO}_{2} \ldots \ldots \ldots \ldots \ldots$ & .0255 \\
\hline $\mathrm{SO}_{4} \ldots \ldots \ldots$ & .1364 & 22.96 & $\mathrm{Al}_{2} \mathrm{O}_{3} \ldots \ldots \ldots \ldots$ & .0035 \\
\hline Cl.......... & .0041 & 0.69 & KCl.................. & .0086 \\
\hline $\mathrm{Al}_{2} \mathrm{O}_{3} \ldots \ldots$ & .0035 & 0.59 & $\overline{\mathrm{K}}_{2} \mathrm{SO}_{4} \ldots \ldots \ldots \ldots$ & .0185 \\
\hline $\mathrm{Ca} \ldots \ldots \ldots$ & .1378 & 23.20 & $\mathrm{Na}_{2} \mathrm{SO}_{4} \ldots \ldots \ldots \ldots$ & .0296 \\
\hline $\mathrm{Mg} \ldots \ldots \ldots$ & $.034 R$ & 5.86 & $\mathrm{CaSO}_{4} \ldots \ldots \ldots$ & .1504 \\
\hline Na........... & .0096 & 1. 61 & $\mathrm{CaCO}_{3} \ldots \ldots \ldots \ldots$ & .2340 \\
\hline \multirow[t]{2}{*}{$\mathbf{K} \ldots \ldots \ldots \ldots$} & .0128 & 2.15 & $\dot{\mathrm{MgCO}}{ }_{3} \ldots \ldots \ldots \ldots$ & .1218 \\
\hline & .3645 & & & .5919 \\
\hline \multirow[t]{2}{*}{$\mathrm{CO}_{3} \ldots \ldots \ldots$} & .2295 & 38.65 & \multirow{2}{*}{\multicolumn{2}{|c|}{99.64 per cent. accounted for. }} \\
\hline & .5940 & 100.00 & & \\
\hline
\end{tabular}

D. -New hot spring.

[Total solids : 0.5740 gramme to the liter.]

\begin{tabular}{|c|c|c|c|c|}
\hline \multicolumn{2}{|l|}{ Found. } & $\begin{array}{l}\text { Per cent. } \\
\text { of total }\end{array}$ & \multicolumn{2}{|c|}{ Probable combination. } \\
\hline $\mathrm{SiO}_{2} \ldots \ldots \ldots$ & .0235 & 4. 09 & $\mathrm{SiO}_{2} \ldots \ldots \ldots \ldots \ldots$ & .0235 \\
\hline $\mathrm{SO}_{4} \ldots \ldots \ldots$ & .1294 & 22.54 & $\mathrm{Al}_{2} \mathrm{O}_{3} \ldots \ldots \ldots \ldots$ & .0060 \\
\hline $\mathrm{Cl} \ldots \ldots \ldots$. & .0029 & 0.50 & $\mathrm{KCl} \ldots . . . . . . . .$. & .0061 \\
\hline $\mathrm{Al}_{2} \mathrm{O}_{3} \ldots \ldots \ldots$ & .0060 & 1.04 & $\mathrm{~K}_{2} \mathrm{SO}_{4} \ldots \ldots \ldots \ldots$ & .0212 \\
\hline $\mathrm{Ca} \ldots \ldots \ldots$. & .1329 & 23.15 & $\mathrm{Na}_{2} \mathrm{SO}_{4} \ldots \ldots \ldots$ & .0278 \\
\hline $\operatorname{Mg} \ldots \ldots \ldots$ & .0351 & 6.13 & $\mathrm{CaSO}_{4} \ldots \ldots \ldots$ & .1401 \\
\hline Na...... & .0090 & 1.57 & $\mathrm{CaCO}_{3} \ldots \ldots \ldots \ldots$ & .2272 \\
\hline $\mathbf{K} \ldots \ldots \ldots$ & .0127 & 2. 21 & $\mathrm{MgCO}_{3} \ldots \ldots \ldots$ & .1228 \\
\hline & .3515 & & & .5747 \\
\hline $\mathrm{CO}_{3} \ldots$ & .2225 & 38.77 & \multirow{2}{*}{\multicolumn{2}{|c|}{ Total, 100.12 per cent. }} \\
\hline & .5740 & 100.00 & & \\
\hline
\end{tabular}

$$
\text { E.-“Sulphur" bath. }
$$

[Total solids : 0.5775 gramme to the liter.]

\begin{tabular}{|c|c|c|c|c|}
\hline \multicolumn{2}{|l|}{ Found. } & \multirow{2}{*}{$\begin{array}{c}\begin{array}{c}\text { Per cent. } \\
\text { of total } \\
\text { solids. }\end{array} \\
3.98\end{array}$} & \multicolumn{2}{|c|}{ Probable combination. } \\
\hline $\mathrm{SiO}_{2} \ldots \ldots \ldots$ & .0230 & & $\mathrm{SiO}_{2} \ldots \ldots \ldots \ldots$ & .0230 \\
\hline $\mathrm{SO}_{4} \ldots \ldots \ldots \ldots$ & .1273 & 22.04 & $\mathrm{Al}_{2} \mathrm{O}_{3} \ldots \ldots \ldots \ldots$ & .0065 \\
\hline Cl........... & .0032 & 0.55 & KCl $\ldots . . . . . . . .$. & .0068 \\
\hline $\mathrm{Al}_{2} \mathrm{O}_{3} \ldots \ldots$ & .0065 & 1.13 & $\mathrm{~K}_{2} \mathrm{SO}_{4} \ldots \ldots \ldots \ldots$ & 0158 \\
\hline $\mathrm{Ca} \ldots \ldots . . .$. & .1318 & 22.82 & $\mathrm{Na}_{2} \mathrm{SO}_{4} \ldots \ldots \ldots \ldots$ & .0420 \\
\hline Mg .......... & .0330 & 5. 71 & $\mathrm{CaSO}_{4} \ldots \ldots \ldots \ldots$ & .1278 \\
\hline $\mathrm{Na}$ & .0136 & 2. 36 & $\mathrm{CaCO}_{3}, \ldots \ldots \ldots \ldots$ & .2355 \\
\hline \multirow[t]{2}{*}{$\mathbf{K}, \ldots \ldots \ldots$} & .0107 & 1.85 & $\mathrm{MgCO}_{3} \ldots \ldots \ldots$ & .1155 \\
\hline & .3491 & & & .5729 \\
\hline \multirow[t]{2}{*}{$\mathrm{CO} \ldots \ldots \ldots$} & .2284 & 39.56 & \multirow{2}{*}{\multicolumn{2}{|c|}{99.20 per cent. accounted for. }} \\
\hline & .5775 & 100.00 & & \\
\hline
\end{tabular}


No $\mathrm{H}_{2} \mathrm{~S}$ nor sulphides were found in this water. The spring, however, is said to have at times a "sulphur odor."

$$
\text { F.-Magnesian spring. }
$$

[Total solids; 0.3825 gramme to the liter.]

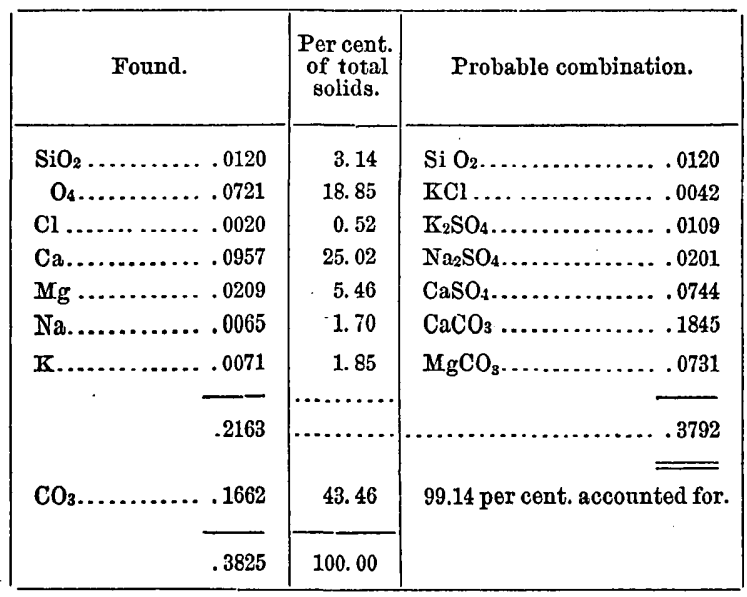

Why this spring is specially named "Magnesian" is not explained. It will be noted that this spring, the coolest of the series, is proportionally richer in carbonates and poorer in sulphates than the others. This relation is shown by a comparison of the percentage columns. 


\section{THE ESTIMATION OF ALKALIES IN SILICATES, BY THOMAS M. CHATARD. .}

Walter Hempel proposed (Fres. Zschr. 1881, p. 496) bismuth subnitrate as a means of decomposing silicates containing alkalies, and recommended the use of 20 parts of this salt ( $=10$ parts of bismuth oxide) to one part of the silicate. In the Berichte d. D. Chem. Gesellsch, 1881, there is an abstract of his paper, in which is proposed the use of bismuth oxide directly.

This process has been in use in this laboratory for the past six months, and, with some modifications, has given great satisfaction. Bismuth oxide has been used instead of the subnitrate, and experience has shown that, instead of ten parts, as stated above, two parts of oxide: to one part of the mineral are ample in every case in which we have employed the method.

The oxide and mineral, both finely powdered, must be most thoroughly mixed, and then heated in a platinum crucible; applying at first a gentle heat and gradually increasing to full redness, which is kept up ten to fifteen minutes. In the case of an acid silicate, complete fusion may result, while the more basic the silicate the less fusible the mixture will be. Complete decomposition has been obtained when the result. ing mass was so slightly sintered together as to fall on gentle pressure into powder, none of which adhered to the crucible. It has therefore been found advantageous, in dealing with acid silicates, to add to the mixture a quantity of calcium carbonate, in weight equal to that of the mineral. This device prevents the fusion which might hinder the after treatment with acid.

After the mass has been thoroughly heated to bright redness it is allowed to cool, placed in a dish, and hydrochloric acid somewhat diluted poured over it. On heating over the water bath the mass should go into solution rapidly, leaving no residue of undecomposed mineral, which is easily distinguishble from floating flakes of silica.

If complete analysis is required, evaporate to dryness and separate the silica, as in a soda fusion, afterwards removing the bismuth by sulphureted hydrogen. If only alkalies are to be determined, add ammonia and ammonium carbonate, filter, and separate magnesia from the alkalies by any of the usual methods. 
The results of this process have been very satisfactory. Out of a large number of analyses the following duplicate has been selected as being sufficient to show the accuracy of the work. It may be remarked that in the case of this margarite (a very basic silicate) the mass was but slightly sintered together.

$$
\text { Margarite.-Gainesville, Ga. }
$$

1.0300 grammes gave 0.0440 alkali chlorides $=0.0233 \mathrm{Na}_{2} \mathrm{O}=2.26$ per cent. 1.0243 grammes gave 0.0435 alkali chlorides $=0.0231 \mathrm{Na}_{9} \mathrm{O}=2.25$ per cent. 



\section{INDEX.}

Abert Iak0 . Page

Alkalies in silicates, estimation of

Allanite .......................................................... 10

Alum rock .................................................... 13

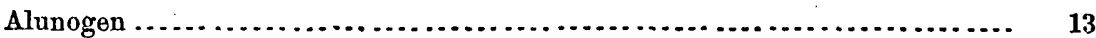

Basalt from Mount Thielson $. . \ldots \ldots \ldots \ldots \ldots \ldots \ldots \ldots \ldots \ldots \ldots \ldots \ldots \ldots \ldots \ldots \ldots \ldots \ldots . \ldots \ldots$

Basalt from Pit River ............................................ 16

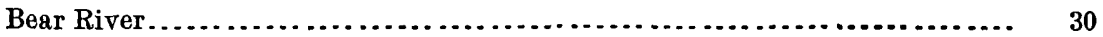

Beryl ...................................................... 11

Boiling Spring, Honey Lake Valley, California . . . . . . . . . . . . . . . . . . . . 28

Cimolite ..................................................... 12

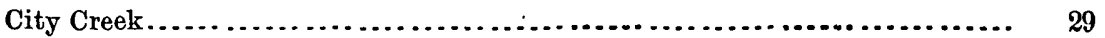

Clays from Mill City, Nevada ..... . . . . . . . . . . . . . . . . . . . . . . . . . . . 15

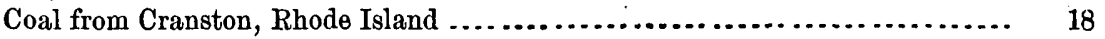

Dacites from Lassen's Peak.............................................. 16

Damourite ................................................... 11

Emigrant Gulch, Warm Springs .................................. 31

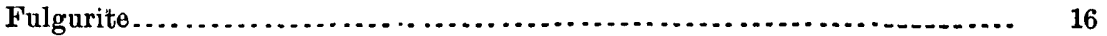

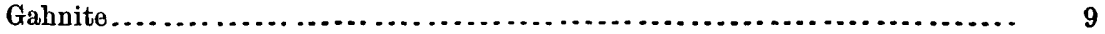

Halloysite ......................................................... 12

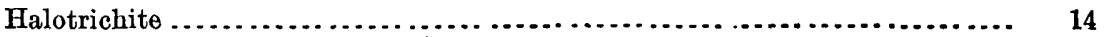

Helena Hot Springs ............................................ 32

High Rock Spring, Honey Lake Valley, California . . . . . . . . . . . . . . . . . . . 28

Hot Spring, Hot Spring Station, Nevada............................ 24 .

Hot Spring, foot of Granite Mountain, Nevada ......................... 24

Humboldt River ................................................... 23

Inclusion in dacite . . . . . . . . . . . . . . . . . .

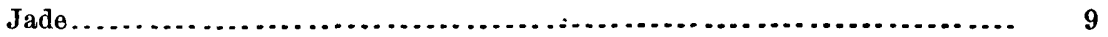

Lahontan beds, powder from $\ldots . \ldots \ldots \ldots \ldots \ldots \ldots \ldots \ldots \ldots \ldots \ldots \ldots \ldots \ldots \ldots \ldots \ldots . \ldots \ldots$

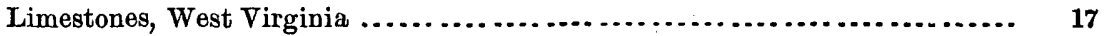

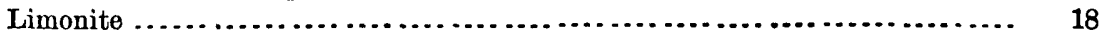

Livingston Warm Springs .......................................... 31

Lower Hot Spring, Honey Lake Valley, California ......................... 28

Magnetite, from Montana.......................................... 17

Margarite........................................................ 11

Marl from Nevada................................................ 14

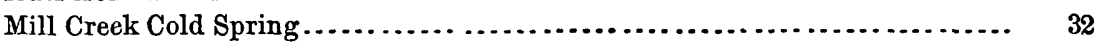

Mono Lake...................................................... 26

Obsidian, scoriaceous............................................... 14

Pectolite...................................................... 9

Petroleum Spring, Mono Lake ..................................... 27

Prochlorite ................................................... 13

Pyramid Lake .................................................... 19

Saussurite ..................................................... 10

Scoriaceous obsidian .............................................. 14

Silicates, estimation of alkalies in . .................................. 36

(279) $\quad 39$ 
Tahoo, Lake ...................................................... 28

Tufa Crag, Mono Lake, spring on................................ 27

Utah Hot springs .............................................. 30

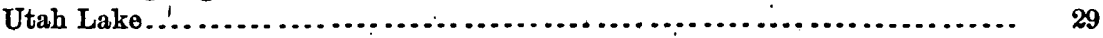

Virginia Hot Springs . ......................................... 33

Walker Lake .................................................. 22

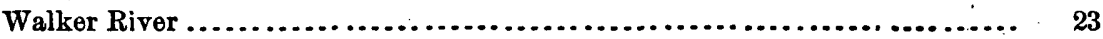

Warm Springs, Emigrant Gulch ..................................... 31

Warm Springs, Mono Basin . . . . . . . . . . . . . . . . . . . . . . . .

Winnemucca Lake .............................................. 21 